\title{
Uma sequência didática para discutir as relações étnico-raciais (Leis $10.639 / 03$ e 11.645/08) na educação científica ${ }^{+}$
}

\author{
Alan Alves-Brito ${ }^{1}$ \\ Instituto de Física - Universidade Federal do Rio Grande do Sul \\ Vitor Bootz ${ }^{1}$ \\ Bacharelando em Astrofísica - Universidade Federal do Rio Grande do Sul \\ Neusa Teresinha Massoni ${ }^{1}$ \\ Instituto de Física - Universidade Federal do Rio Grande do Sul \\ Porto Alegre - RS
}

\section{Resumo}

Um dos grandes desafios da Educação Básica do Brasil do século XXI é a implementação das Leis 10.639/03 e 11.645/08, as quais tornam obrigatória a inclusão do ensino da História da África, da Cultura AfroBrasileira e Indígena, nos currículos dos estabelecimentos de ensino do País, na luta por uma sociedade mais igualitária. No entanto, do ponto de vista prático, o debate atual em torno dessas Leis bem como das práticas pedagógicas e didáticas desenvolvidas nas escolas estão quase que exclusivamente restritas às iniciativas feitas no contexto de disciplinas das Ciências Humanas e Sociais. Ancorado em referenciais teóricos da Astronomia Cultural e da Pedagogia Dialógica de Paulo Freire, o presente trabalho apresenta uma Sequência Didática diversificada com o objetivo de permitir, nas aulas de Ciências/Física da Educação Básica, embora ela possa também ser aplicada no Ensino Superior, uma ampla discussão acerca dos pressupostos históricos, culturais e científicos do céu Africano, Indígena e do assim denominado céu Ocidental. Tomando as constelações em variadas culturas como ponto de partida, o presente trabalho soma-se às iniciativas que buscam articular a garantia de direitos humanos e sociais e o respeito à diversidade étnico-racial. Trata-se,

\footnotetext{
${ }^{+}$A proposal of didactic sequence to discuss ethnic-racial relations (Laws 10.639/03 and 11.645/08) in the classes of Sciences and Physics

* Recebido: maio de 2018.

Aceito: agosto de 2018.

${ }^{1}$ E-mails: alan.brito@ufrgs.br; vitorbootz@gmail.com; neusa.massoni@if.ufrgs.br
} 
assim, de um exemplo simples, por meio de um objeto virtual de aprendizagem e de um material didático construído em sala, de como aulas de Ciências/Física podem contribuir nos Ensinos Fundamental e Médio, com uma educação mais crítica, antidiscriminatória, antirracista, emancipatória e diversa, levando em conta as diferentes alteridades, ou seja, o "outro".

Palavras-chave: Ensino de Ciências; Física e Astronomia; Diálogo Intercultural; Relações Étnico-raciais.

\begin{abstract}
One of the greatest challenges of the basic education in Brazil in the 21st Century is the implementation of Laws 10.639/03 and 11.645/08, which make compulsory to include the teaching of History of Africa, AfroBrazilian and Indigenous Culture in the curricula of Brazil's educational institutions, in the fighting for a more egalitarian society. However, from the practical point of view, the current debate around the cited Laws as well as the pedagogical and didactic practices developed in the schools are almost exclusively restricted to the initiatives made within the disciplines of the Human and Social Sciences. Anchored in theoretical references of Cultural Astronomy and Paulo Freire's Dialogical Theory, the present work presents a diversified Didactic Sequence with the objective of allowing, in the classes of Sciences and Physics of basic education, although the Didactic Sequence can also be applied in higher education, a large discussion about the historical, cultural, and scientific assumptions of the African, Indian and so-called Western sky. Having constellations in various cultures as a starting point, the present work joins initiatives that seek to articulate the guarantee of human and social rights and respect for ethnic-racial diversity. It is, therefore, a simple example, through a virtual object of learning and a didactic material constructed in class, of how Science and Physics classes can contribute in the basic education, with a more critical, antiracist, emancipatory and diverse education, taking into account the different alterities, that is, the "other".
\end{abstract}

Keywords: Teaching of Sciences; Physics and Astronomy; Intercultural Dialogue; Ethnic-racial Relations. 


\section{Relações étnico-raciais: um debate necessário nas aulas de Ciências/Física}

Levando em conta uma longa trajetória e a complexa História do Brasil, que é marcada por mais de 400 anos de um severo sistema de tráfico internacional transatlântico de cativos $^{2}$ (SCHWARCZ; STIRLING, 2015), a Lei 10.639, instituída em janeiro de 2003, representa um dos marcos antirracismo mais importantes da história da Educação Brasileira ao alterar a Lei de Diretrizes e Bases (BRASIL, 1996: lei 9.394) para regulamentar a obrigatoriedade do ensino e do estudo da História e Cultura Afro-Brasileira e dos Povos Africanos nos currículos dos estabelecimentos dos sistemas educacionais (públicos e particulares) brasileiros. Nesta mesma direção vai a Lei 11.645, promulgada em março de 2008, que altera a LDB e complementa a lei 10.639/03, acrescentando a obrigatoriedade da inclusão de temáticas relativas à História e Cultura das Populações Indígenas, que têm sido historicamente oprimidas e alijadas de direitos, sobretudo o direto à educação científica que leve em conta as suas próprias histórias e epistemologias. Estas duas leis representam assim a oportunidade histórica que o País tem de descolonizar os currículos da visão eurocêntrica do mundo e entender a diversidade da sociedade brasileira traduzida em diferenças de raça, classe, sexo, gênero, crenças, cultura, entre outros marcadores sociais (FERNANDES; CINEL; LOPES, 2016).

A Resolução $n^{\circ} 1$ do Conselho Nacional de Educação, de 7 de junho 2004, em seu Artigo $2^{\circ}$ diz que:

Art. $2^{\circ}$ As Diretrizes Curriculares Nacionais para a Educação das Relações ÉtnicoRaciais e para o Ensino de História e Cultura Afro-Brasileira e Africanas constituem-se de orientações, princípios e fundamentos para o planejamento, execução e avaliação da Educação, e têm por meta, promover a educação de cidadãos atuantes e conscientes no seio da sociedade multicultural e pluriétnica do Brasil, buscando relações étnico-sociais positivas, rumo à construção de nação democrática.

$\S 1^{\circ}$ A Educação das Relações Étnico-Raciais tem por objetivo a divulgação e produção de conhecimentos, bem como de atitudes, posturas e valores que eduquem cidadãos quanto à pluralidade étnico-racial, tornando-os capazes de interagir e de negociar objetivos comuns que garantam, a todos, respeito aos direitos legais e valorização de identidade, na busca da consolidação da democracia brasileira.

$\S 2^{\circ} \mathrm{O}$ Ensino de História e Cultura Afro-Brasileira e Africana tem por objetivo o reconhecimento e valorização da identidade, história e cultura dos afro-brasileiros, bem como a garantia de reconhecimento e igualdade de valorização das raízes africanas da nação brasileira, ao lado das indígenas, européias, asiáticas (BRASIL, 2004).

Desta forma, nota-se que com o objetivo de promover a igualdade étnico-racial por meio da representação positiva do legado histórico, social e cultural dos povos historicamente

\footnotetext{
2 Evita-se, neste texto, palavras que denotem ou reproduzem o sequestro e a visão de escravização da memória de um processo que é, historicamente, a submissão de pessoas livres, em seus direitos e dignidade, ao trabalho escravo.
} 
excluídos do sistema educacional do País, a recomendação do MEC e das Diretrizes Curriculares Nacionais é de que o estudo sistemático e contextualizado destes povos dê-se, em sala de aula, de forma a perpassar todo o currículo escolar, conectando disciplinas, (con)vivências e experiências e atingindo não apenas as pessoas alvo das Leis citadas.

A LDB em seu Art. 26-A, que foi acrescido em função da Lei 11.645 de 2008, dispõe:

Art. 26-A. Nos estabelecimentos de ensino fundamental e de ensino médio, públicos e privados, torna-se obrigatório o estudo da história e cultura afro-brasileira e indígena.

$\S 1^{\circ} \mathrm{O}$ conteúdo programático a que se refere este artigo incluirá diversos aspectos da história e da cultura que caracterizam a formação da população brasileira, a partir desses dois grupos étnicos, tais como o estudo da história da África e dos africanos, a luta dos negros e dos povos indígenas no Brasil, a cultura negra e indígena brasileira e o negro e o índio na formação da sociedade nacional, resgatando as suas contribuições nas áreas social, econômica e política, pertinentes à história do Brasil.

$\S 2^{\circ}$ Os conteúdos referentes à história e cultura afro-brasileira e dos povos indígenas brasileiros serão ministrados no âmbito de todo o currículo escolar, em especial nas áreas de educação artística e de literatura e história brasileiras (BRASIL, 1996).

Entende-se que a ciência, como construção humana, indissociável das dimensões histórica e social, precisa ser diversa e sua educação requer pedagogias, novas estratégias e procedimentos de ensino e aprendizagem diversificados e (res)significados na contemporaneidade, perpassando "todo o currículo escolar"; é preciso, assim, na perspectiva de atendimento das políticas públicas antes mencionadas, despertar na sociedade a importância de se educar para as relações étnico-raciais em todas as dimensões possíveis da existência - ontológica, pedagógica, política, histórica, cultural e social da diferença (GOMES, 2007; FERNANDES; CINEL; LOPES, 2016).

No entanto, alternativamente às expectativas gerais, passados 15 e 10 anos, respectivamente, desde que as Leis 10.639/03 e 11.645/08 entraram em vigor, nota-se que a discussão e o estudo de estratégias para a execução destas leis, no Ensino Básico, restringem-se quase que exclusivamente a áreas como Artes, Literatura e História Brasileiras ( $\$ 2^{\circ}$ do Art. 26-A da LDB). É importante perceber que não apenas as Artes e as Ciências Humanas e Sociais têm a missão de formar para a cidadania, senão todas as áreas do conhecimento humano, nos seus diversos níveis, da Educação Infantil ao Ensino Superior. Além disso, nota-se que com raras exceções os poucos materiais disponíveis sobre os temas étnico-raciais em ciências exatas, sobretudo em se tratando de Física e Astronomia (JAFELICE, 2015), estão restritos a artigos científicos técnicos da área que (i) ou não chegam ao conhecimento dos professores da rede básica de ensino (ii) ou são incompreendidos pelos mesmos, dificultando a criação de materiais adaptáveis à realidade dos alunos e do Ensino Básico. 
Estatisticamente, como revelam Santana, Farias e Rebelo-Pinto (2017), mesmo na Bahia, estado majoritariamente composto por pessoas negras (pretos e pardos; IBGE, 2017: censo demográfico), muitos professores da educação básica (70\% de uma amostra de 52 professores entrevistados) não conhecem as duas leis ou não as mencionam em suas atividades cotidianas. Mesmo os poucos professores que as conhecem relatam sentir muita dificuldade para tratá-las de forma didática em sala de aula. Os resultados da referida pesquisa revelam as tensões entre o currículo e a práxis; escancaram o abismo que há entre o que preconiza a legislação vigente e o estabelecimento, na prática, das políticas públicas voltadas à valorização do conhecimento e às contribuições históricas dos povos indígenas, africanos e afrobrasileiros no Brasil. De fato, pode-se dizer que temos boas leis, mas há um abismo entre escrever uma boa lei e colocá-la em prática.

No caso das disciplinas voltadas para as chamadas ciências exatas (Física, Química, Matemática, Engenharia, Tecnologia) a situação é ainda mais crítica, pois estes campos do conhecimento têm sido historicamente dominados no Brasil (embora seja esta a realidade mundial) por homens brancos, heterossexuais e de classe média (JUNIOR; OSTERMANN; REZENDE, 2011a; JUNIOR; REZENDE; OSTERMANN, 2011b; LIMA; BRAGA; TAVARES, 2015; SANTOS, 2017). Há, de fato, uma sub-representação de mulheres nas ciências exatas, sendo a Física um caso crônico (LIMA; BRAGA; TAVARES, 2015; MENEZES et al., 2018). Vale, no entanto, destacar que a sub-representação de negros e negras e indígenas nas ciências exatas é mais dramática (LIMA et al., 2014; SANTOS, 2017; ROSA, 2018a, b); quando se considera o fato de que negros e pardos representam cerca de $54 \%$ da população brasileira, eles são a maioria pobre do País (IBGE, 2017).

Em 2013 o MEC, em uma ação alusiva aos 10 anos da Lei 10.639, lança o Plano Nacional de Implementação das Diretrizes Curriculares Nacionais para a Educação das Relações Étnico-Raciais e para o Ensino de História e Cultura Afro-Brasileira e Africana e reforça que práticas pedagógicas e rotinas educacionais devem estar orientadas para relações sociais igualitárias, alinhadas a iniciativas internacionais como, por exemplo, a III Conferência Mundial Contra o Racismo, Discriminação Racial, Xenofobia e Intolerância Correlata realizada na África do Sul, em 2001. Reconhecendo a dificuldade de implementação das leis, o Plano Nacional reafirma que esforço constante de todos os entes federativos e seus sistemas de ensino é necessário para que se cumpram as determinações legais, e especifica seis eixos estratégicos. O eixo 3 é a "política de matéria didática e paradidática" envolvendo inclusive o PNLD 3 para que os livros didáticos promovam positivamente valores, tradições, organizações, saberes e a cultura afro-brasileira. No documento, o MEC estabelece atribuições e responsabilidades aos diferentes agentes da educação brasileira, sendo que as instituições de ensino superior, principalmente aquelas que mantêm programas de formação inicial e continuada de professores, devem incluir disciplinas, atividades acadêmicas e de pesquisa sobre a educação para as

${ }^{3}$ PNLD - Plano Nacional do Livro Didático. 
relações étnico-raciais. Um ponto de destaque é a produção e análise crítica de livros e materiais didáticos consonantes com essa política pública (BRASIL, 2013).

Assim, as Diretrizes Curriculares Nacionais para a Formação Inicial e Continuada em Nível Superior de Profissionais do Magistério para a Educação Básica (BRASIL, 2015), alinhadas ao documento de 2013, orientam que os programas e cursos de formação inicial e continuada sejam estruturados e desenvolvidos por meio da articulação entre as instituições de educação superior e os sistemas de educação básica; preconizam que os diferentes cursos de formação garantam nos currículos, não apenas conteúdos específicos da respectiva área de conhecimento articulados aos conhecimentos pedagógicos (fundamentos teóricos e metodológicos), mas também conteúdos relacionados à diversidade étnico-racial, sexual e de gênero no Brasil. Consequentemente, as ciências exatas, até em função do dramático quadro brevemente apresentado neste texto, não podem estar alijadas do crítico e fundamental debate em torno das questões étnico-raciais na educação básica; as ciências exatas não podem calar-se frente à realidade das novas demandas da sociedade e da educação básica do século XXI, como é o caso das questões identitárias.

Desta forma, levando em conta as prerrogativas legais e as recomendações de resultados recentes de pesquisa em educação científica (ARAÚJO; VERDEAUX; CARDOSO, 2017), o principal objetivo deste artigo é refletir sobre a necessidade e o desafio de se pensar uma educação científica, sobretudo nas ciências exatas, que leve em conta as questões étnicoraciais em sala de aula.

Nessa linha, apresentamos uma sequência didática, que gera inclusive um recurso digital, como uma proposta estratégica e viável para levar professores e estudantes da Educação Básica e da Educação Superior a compreenderem que é também seu papel o de combater, em aulas de Ciências/Física, a discriminação étnico-racial e de contar uma outra história, tão legítima quanto a tradicionalmente ensinada - cultura e história ocidental, que é a da presença da população indígena e afro-brasileira, para além das aulas de "tráfico étnico e racial de pessoas".

\section{Contexto do projeto}

A Sequência Didática aqui descrita foi desenvolvida no âmbito do Programa de Iniciação Científica "Ciência na Escola, Ciência na Sociedade" da Pró-Reitoria de Pesquisa da Universidade Federal do Rio Grande do Sul para ser trabalhada com professores e estudantes da Educação Básica. Trata-se de um projeto diversificado, no sentido de que se afasta do modelo tradicional baseado em transmissão de conhecimentos e busca um compromisso com a educação "desvestida da roupagem alienada e alienante", educação como "força de mudança e de libertação" e de escolha do próprio caminho (FREIRE, 1967, p. 36); uma educação que propõe a discussão, nas aulas de Ciências/Física na Educação Básica, das leis 10.639/03 e 11.645/08. Tal debate, quando presente, é fortemente relegado às ciências humanas e sociais, como já dito. 
O projeto surge também como uma inquietação dos autores visando discutir, no Instituto de Física da UFRGS, as razões da sub-representação de pessoas negras e/ou indígenas nos cursos de Licenciatura e Bacharelado em Física, mesmo sendo o Rio Grande do Sul um estado com cerca de 17\% da população autodeclarada preta ou parda (IBGE, 2017).

Como parte de um projeto de interlocução com a escola básica, pretende-se, desta forma, propor maneiras de descolonizar os currículos de ciências (especialmente os de ciências exatas), aliando Astronomia e objetos virtuais de aprendizagem, que é outro gargalo na educação básica. Embora o presente texto esteja focado em um objeto virtual de aprendizagem, assume-se que as discussões em Astronomia na Educação Básica não estejam desvinculadas da experiência singular de observar o próprio céu noturno.

Busca-se, com esta Sequência Didática, valorizar as alteridades e as identidades culturais do País no contexto das aulas de Ciências/Física, levando para a escola básica mecanismos distintos de valorização das culturas e de promoção de uma educação mais inclusiva, pautada no direito à educação plena e democrática. Ao mesmo tempo, trata-se de um estímulo ao uso de objetos virtuais de aprendizagem nas escolas da educação básica, propondo formas alternativas de representações físicas e simbólicas e de práticas cristalizadas no campo conflituoso e tenso do currículo (historicamente propedêutico para classes socioeconomicamente mais privilegiadas e, profissionalizante, para as classes populares).

Exposta a diferentes aparatos tecnológicos que transformaram a vida da moderna sociedade, e a uma excessiva e variada quantidade de informação no quotidiano, grande parte dos estudantes já chega às escolas dominando muitos destes códigos tecnológicos, de forma que a sala de aula, baseada apenas em situações convencionais de aprendizagem, acaba por se revelar desestimulante. Vale frisar, no entanto, que nessa sociedade da informação a figura do professor é indispensável na escola, já que informação não significa, necessariamente, produção crítica e libertadora de conhecimento.

Paulo Freire, que nos serve de referencial teórico, assevera que quem observa o faz de certo ponto de vista, o que não situa o observador em erro. O erro está em absolutizar nosso ponto de vista e desconhecer que, mesmo estando em acerto, é possível que a razão ética nem sempre esteja com ele. Especialmente na educação para a autonomia, o professor precisa estar atendo à responsabilidade de sua presença, sua postura deve ser de respeito à pessoa (o outro) e ao seu direito de aceitá-la ou rejeitá-la (FREIRE, 1996). Por outro lado, as demandas da educação de nossos tempos não abarcam apenas a inclusão tecnológica, mas, principalmente, a inclusão social. A ciência, em particular as ciências exatas, precisa de diversidade. E, na Educação Básica, é urgente discutir a diversidade na perspectiva da própria ciência. Pobres, negros e negras, brancos e brancas, índios e índias, homens e mulheres, professores universitários e da Educação Básica, além de outros setores da sociedade precisam estar conectados em redes de conhecimento para garantir a diversidade na escola e na ciência.

Nessa perspectiva, nosso objetivo na presente proposta é apresentar alternativas para: a) propiciar um estudo sistemático das constelações e do céu de povos indígenas e africanos 
que estão disponíveis no objeto virtual de aprendizagem Stellarium, como ferramenta tecnológica voltada ao ensino-aprendizagem (CECÍLIO JUNIOR, 2016; WOLF, 2017); b) fomentar as discussões relevantes para as ciências exatas da contemporaneidade, principalmente aquelas associadas a relações étnico-raciais (FERNANDES; CINEL; LOPES, 2016) e a Astronomia Cultural (ARAÚJO; VERDEAUX; CARDOSO, 2017).

De maneira genérica, um objeto virtual de aprendizagem é uma ferramenta digital que auxilia na aprendizagem de conceitos e, paralelamente, estimula o desenvolvimento de qualidades como imaginação e criatividade. O Stellarium é um código gratuito de simulação do céu. O/a observador/a pode ser colocado/a em qualquer lugar do planeta. O céu observável pode ser explorado em um amplo intervalo de horas, dias e anos. O código carrega mais de 600 mil imagens de diferentes objetos e fenômenos astronômicos e tem um módulo inteiro devotado à constelações e seus significados em diferentes culturas. A sequência didática (SD) é entendida como diversificada na medida em que vários astrônomos/pesquisadores (CARDOSO, 2016) interagiram com diferentes culturas (africanas e indígenas) e disponibilizaram diferentes interpretações/entendimentos das constelações/do céu no Stellarium, mas não encontramos propostas didáticas que explorassem esses diferentes significados, e, em especial, associando-os às questões étnico-raciais. A SD surge também com a incumbência de ressignificar os ociosos laboratórios de informática das escolas públicas de Educação Básica. Professores de Ciências, História, Geografia, além de estudantes e demais interessados, poderão não apenas trabalhar conceitos científicos fundamentais que envolvem a estrutura e organização das constelações, mas, sobretudo, estarão aptos a discutir os elementos criativos e culturais por trás do processo de estabelecimento destas constelações. Assim, como já dito, a exploração do Stellarium torna possível usar o estudo do céu do passado e o céu do presente para discutir diferentes saberes, em respeito às Leis 10.639/03 e 11.645/08. Espera-se, assim, contribuir para a reflexão da diversidade na escola, trazendo, sobretudo, para a sala de aula, as questões mais básicas no que tange às contribuições de indígenas, africanos e comunidades afro-brasileiras ao conhecimento e à sociedade.

Objetivamente, a SD aqui apresentada pretende:

(i) Fazer valer, nas aulas de Ciências/Física, as leis 10.639/03 e 11.645/08, que alteram a Lei de Diretrizes e Bases da Educação Nacional (BRASIL 1996).

(ii) Promover a valorização da diversidade étnico-racial, em particular a cultura indígena, afro-brasileira e africana, de forma a superar a discriminação étnico-racial (ainda) presente no sistema educacional brasileiro.

(iii) Buscar semelhanças e diferenças entre o céu das diferentes culturas analisadas, não com o intuito de hierarquizá-las.

(iv) Contribuir, por meio da Astronomia Cultural e do Stellarium, para o estabelecimento da cultura científica na Educação Básica, entendendo o conhecimento científico como construção humana, histórica, social, cultural e política. 
(v) Problematizar a situação crônica da falta de representatividade de negros, negras e indígenas nas carreiras científicas, principalmente nas ciências exatas.

(vi) Discutir conceitos científicos (ciências exatas e humanas) e culturais no que tange à materialização do céu visível, com ligações ao passado e ao presente, refletindo as conexões entre o céu (identidades culturais) e a terra (território, lugar, diáspora ${ }^{4}$ ).

(vii) Dar novo sentido ao uso dos laboratórios de informática nas escolas públicas da Educação Básica, apropriando-se de softwares gratuitos encontrados na internet (Stellarium, Google MyMaps, entre outros) para estabelecer uma cultura científica abrangente, expandindo os horizontes numéricos e valorizando o pensamento e o comportamento dos diferentes povos (africanos, afro-brasileiros e indígenas) na interpretação e dinâmica celeste ao longo do ano.

(viii) Elaborar, para alunos e professores da educação básica, materiais didáticos focados em novas metodologias de ensino-aprendizagem com ênfase em Astronomia Cultural.

(xi) Contribuir com a formação inicial e continuada de professores mais críticos e reflexivos.

\section{Referencial teórico}

A SD está alicerçada em duas vertentes de estudo como descrito brevemente na sequência.

\section{III.1 Astronomia Cultural}

A Astronomia, conforme um texto introdutório e atual (OLIVEIRA FILHO; SARAIVA, 2014 ${ }^{5}$ ) é uma das ciências básicas mais atraentes para públicos variados (crianças, jovens e adultos). A disciplina Explorando o Universo - dos Quarks aos Quasares, por exemplo, que é oferecida semestralmente pelo Departamento de Astronomia do Instituto de Física aos diferentes cursos de graduação da UFRGS, bem como para a comunidade externa à universidade, tem larga aceitação e recebe cerca de 300 estudantes por semestre. Parte do fascínio exercido por esta ciência se explica por razões históricas, sendo a Astronomia a mais antiga das ciências e ligada, ao longo dos séculos, ao desenvolvimento do exercício do pensamento (LANGHI; NARDI, 2012). Embora os cursos de graduação em Astronomia e/ou Física com ênfase em Astrofísica do Brasil sejam de Bacharelado, vale lembrar que os conteúdos de Astronomia perpassam não apenas o currículo da Educação Básica — da educação infantil ao ensino médio - , mas também disciplinas de cursos variados do ensino superior (Física, Matemática, Química, Biologia, Licenciatura em Educação do Campo, Licenciatura em Ciências da Natureza, Geografia, Filosofia, entre outros) e está presente em muitos ambi-

\footnotetext{
${ }^{4}$ Origina-se da palavra grega dia (através, por meio de) speiró (dispersão, disseminação).

${ }^{5}<$ http://astro.if.ufrgs.br>
} 
entes de educação não formal do País (planetários, museus de ciências, observatórios, entre outros). Os diversos documentos públicos que embasam e orientam nosso Ensino Fundamental e Médio (Brasil 1997; 1998a; 1998b; 1999; 2002; 2008a; 2008b), bem como a Base Nacional Comum Curricular ${ }^{6}$, apesar das controvérsias em torno deste último documento, indicam na Educação Básica o estudo da Astronomia na área de Ciências da Natureza (especialmente na Física) em eixos temáticos que tratam da Terra, da Vida e do Universo (origens e compreensão humana). Temos notado, contudo, em nossas próprias experiências em projetos de extensão e em investigações articuladas ao sistema de ensino básico de Porto Alegre e região metropolitana, bem como em nossas experiências como Professores de Física e Astronomia no ensino superior, que os estudantes da Educação Básica passam grande parte de sua formação focados apenas em conceitos básicos envolvendo o sistema Sol-Terra-Lua, isso quando conseguem ter acesso a tópicos de Astronomia e de Física (DANTAS, 2017, por exemplo, constatou que a maioria dos professores de Ciências de dez escolas da rede pública de Ensino Fundamental de Porto Alegre investigadas, não aborda temas de Física/Astronomia, pois sua formação não é na área de Física e/ou Astronomia e não se sente preparada para discutir esses temas).

Além disso, nota-se que o ensino de Astronomia nem sempre é associado ao potencial que a mesma tem para introduzir em sala de aula temas de interesse na interface com as ciências humanas e sociais. Por exemplo, uma dimensão investigativa que é característica fundamental das ciências, dificilmente é trabalhada na escola.

Dito isto, o referencial teórico do presente artigo ampara-se em resultados de pesquisas em educação científica voltadas para a área de Astronomia Cultural ou Astronomia nas Culturas (LÓPEZ, 2001; ALBUQUERQUE et al.. 2011; LIMA, et al., 2014; JAFELICE, 2015; ARAÚJO, 2014; ARAÚJO; VERDEAUX; CARDOSO, 2017), resultados estes que buscam investigar como as relações físicas e simbólicas de construções, alinhamentos, rituais, caminhos, moradias, manifestações artísticas e religiosas de diferentes povos e sociedades se conectam com o céu visível e são passadas de uma geração a outra, usando diferentes mecanismos de linguagem (oral e escrita). Para Forquin (1993), a cultura é o elemento fundamental do processo educativo; é a partir da cultura que as ações educacionais são construídas e suas finalidades, justificadas. Além disso, a construção de alternativas curriculares, como possibilidade de contribuição para a emancipação social, demanda: 1) clareza acerca do significado de currículo que, muito mais do que uma lista de conteúdos, é a criação cotidiana de todos os que fazem parte da escola, é prática que envolve todos os saberes e processos interativos de professores e estudantes; 2) levar em conta os locais, pois vivências curriculares não ocorrem somente no interior de escolas, mas a vida cotidiana tem seus próprios currículos, expressos nos processos sociais de aprendizagem que permeiam nosso estar no mundo e que vão constituindo nossas identidades e nossa história (SILVA, 1999).

\footnotetext{
${ }^{6}<$ http://basenacionalcomum.mec.gov.br>
} 
De maneira um tanto objetiva, Jafelice (2015) afirma que o significado de astronomia cultural é o de uma área (assentada na abordagem antropológica) que faz "tentativas de entendimento e de tradução de como outras culturas, do passado ou do presente, se relacionam com aquilo que no nosso recorte, ocidental, chamamos de céu" (ibid., p. 61), que permite abordar conteúdos com um espírito, a um só tempo, crítico e integrador (JAFELICE, 2010).

O céu observável (cometas, planetas, satélites naturais, estrelas, galáxias, entre outros) conta a história de diferentes povos e materializa diferentes identidades culturais. A Astronomia nas Culturas trata-se, portanto, de uma área de conhecimento na interface entre as Ciências Humanas e Sociais e as Ciências da Natureza. E, mais importante, o número de trabalhos voltados para este ramo da Astronomia é, como mostram Araújo, Verdeaux e Cardoso (2017), escasso: de 198 artigos publicados entre 2002 e 2016 em Ensino de Astronomia, apenas três estavam direcionados ao estudo da Astronomia Cultural, todos focados em Etnoastronomia Indígena Brasileira (FARES et al., 2004), e dois trabalhos apenas apresentavam propostas didáticas para o ensino da Astronomia Indígena (JAFELICE, 2015; GARCIA et al., 2016).

\section{III.2 Pedagogia Dialógica de Paulo Freire}

A pedagogia de Freire é utilizada aqui não tanto em sua dimensão prática, no sentido de começar a Sequência Didática através de um levantamento de "palavras geradoras" (ou temas geradores) que fazem parte do universo vocabular dos alunos, com referência a situações reais, como fazia Freire nos círculos de cultura (ainda que em certos aspectos nos inspiremos nessas ações), mas especialmente em sua dimensão política e social, tomando com clareza um de seus princípios fundamentais: a ideia de que liberdade adquire plena significação quando comunga com a luta de homens e mulheres, negros e negras, afrodescendentes e indígenas por libertar-se, por um contínuo (re)tomar reflexivo de seus próprios caminhos (FREIRE, 1987, p. 5), pelo resgate de sua cultura, de seus saberes, de sua identidade. Este é o sentido do planejamento do que chamamos de Momento Didático 1: questionar sobre as leis 10.639/03 e 11.645/08, seus significados, sugerir comparações, ouvir e debater sobre etnias, direitos, demandas sociais, culturas, saberes, etc. A SD começa e termina com diálogos reflexivos.

Do ponto de vista da educação libertadora, focada sobretudo no estudante, o professor, segundo Freire (1996), deve preocupar-se em levar para o contexto da sala de aula as mais diferentes situações de aprendizagem, abdicando da noção de que ensinar é transferir conhecimento, assumindo uma postura de que quem forma se forma e re-forma ao formar e quem é formado forma-se e forma ao ser formado (ibid., p. 23); uma postura de oferecer possibilidades e estar ao lado dos educandos para que se tornem reais sujeitos da construção e reconstrução do saberes ensinados, focado não apenas no conteúdo mas, principalmente, na aprendizagem crítica dos estudantes. As discussões étnico-raciais e as reflexões sobre o im- 
pacto das Leis 10.639/03 e 11.645/08 nas aulas de Ciências e Física colocam, desta forma, a Pedagogia Dialógica freireana como uma das bases teóricas de nossa Sequência Didática.

Creio que uma das qualidades essenciais que a autoridade docente democrática deve revelar em suas relações com as liberdades dos alunos é a segurança em si mesma. É a segurança que se expressa na firmeza com que atua, com que decide, com que respeita as liberdades, com que discute suas próprias posições, com que aceita rever-se (FREIRE, 1996, p. 91).

No trecho, Freire nos ensina que autoridade, que é indispensável na prática educativa, não pode ser confundida com autoritarismo. Para ele, o diálogo é uma atividade pedagógica por excelência. Sua luta, seu interesse e sua opção sempre foi por uma "nova sociedade, que, sendo sujeito de si mesma, tivesse no homem e no povo sujeitos de sua História. Opção por uma sociedade parcialmente independente ou opção por urna sociedade que se "descolonizasse" cada vez mais" (FREIRE, 1967, p. 35). Para o autor, os "temas geradores" podem ser localizados em círculos concêntricos, partindo do mais geral (ou seja, do caráter mais universal) ao mais particular e para que o sujeito alcance um pensar crítico é preciso decodificar seus significados em um constante movimento de ida e volta, do concreto ao abstrato.

Delizoicov (2008) sistematiza essa ideia propondo que o planejamento de uma unidade didática para abordar um tema de interesse pode ser feito em termos de três "momentos pedagógicos": 1) Problematização Inicial: momento de apresentação de problematizações a partir de temas significativos para os estudantes, que suscitem discussões, troca de ideias, opiniões e promovam um distanciamento crítico e a percepção da necessidade de aquisição de novos conhecimentos; 2) Organização do conhecimento: quando o professor sistematiza,aprofunda os conteúdos e conceitos, propõe atividades para facilitar sua interpretação científica; 3) Aplicação do conhecimento: momento de potencializar a externalização e o nível de conscientização dos conceitos e teorias científicas, de complementar e retomar as problematizações iniciais, agora incentivando atividades de explicação, argumentação e exercício da capacidade crítica de aplicar o tema estudado e ressignificar sua realidade vivencial.

Entendemos que o vínculo entre conhecimento científico (seu objeto e sua natureza) e as questões de identidade e poder, raça e etnia, que emergem dos campos "minados" e tensos do currículo eurocentrizado podem ser criticamente abordados na perspectiva freiriana. As ideias de Freire foram escolhidas, como dito, porque giram fundamentalmente em torno da noção de educação libertadora, pautada no debate e no diálogo de ideias. Este diálogo não é vertical, de cima (professor) para baixo (estudantes), mas visa ouvir, reconhecer e valorizar o contexto e os marcadores históricos e sociais dos estudantes, suas ideias, saberes, linguagens cotidianas, visões de mundo, conhecimentos e crenças, na busca da construção de sentido para a educação científica. É imprescindível valorizar a comunhão entre as pessoas envolvidas na "rede" e a discussão crítica dos conhecimentos e saberes vivenciais e, aos poucos, avançar organizando o conhecimento de forma a despertar a curiosidade epistemológica. A educação problematizadora é ela mesma baseada no diálogo, na relação dialógico-dialética entre educa- 
dor e educando. Ela não visa criar problemas, mas, por meio do diálogo, levantar questionamentos, refletindo as questões no contexto social que se quer "diferente". Neste sentido, os temas étnico-raciais precisam ser trazidos para o centro do debate, também nas ciências exatas. É preciso, primeiro, tirá-los da invisibilidade para depois fazer com que ocupem os espaços de poder e possam agir como "ação transformadora".

\section{Descrição da Sequência Didática}

\section{IV.1 A proposta}

Com base nos referenciais teóricos que foram fontes de inspiração no presente trabalho, apresentamos, no Quadro 1, os tópicos centrais, conteúdos, objetivos, recursos usados e sugestão de tempo de realização de quatro Momentos Didáticos ${ }^{7}$ da $\mathrm{SD}$ aqui descrita. Os Quadros 1-5 resumem as metodologias usadas bem como sugerem questões étnico-raciais que podem ser abordadas em cada Momento Didático com suas respectivas "proposta de avaliação". Vale lembrar que os tópicos de Astronomia discutidos na SD estão em sinergia com o que orientam os documentos oficiais, sobretudo os $\mathrm{PCN}+$, que sugerem algumas práticas em sala de aula (nos Ensinos Fundamental e Médio), no Brasil, como: (i) a identificação das escalas de tempo dos objetos celestes (dia, mês e ano) com o regulamento das nossas atividades diárias (dia e noite); (ii) as componentes de movimento da Terra (rotação, revolução e precessão); (iii) descrição dos períodos diários (dia e/ou noite) em que o Sol e as demais estrelas estão visíveis no céu; (iv) caracterização de sistemas de referência para observação dos astros; (v) identificação de constelações no céu com o apoio de recursos pedagógicos atuais como mapas celestes, aplicativos, objetos virtuais de aprendizagem entre outros); (vi) valorização da prática de observação e contemplação do céu interpretando-o como parte da cultura.

Quadro 1 - Resumo dos quatro Momentos Didáticos indicados na SD.

\begin{tabular}{|c|c|c|c|c|}
\hline $\begin{array}{l}\text { Momento } \\
\text { Didático }\end{array}$ & Conteúdo & Objetivos & Recurso & Tempo \\
\hline 1 & $\begin{array}{l}\text { Leis } 10.639 / 03 \\
\text { e } 11.645 / 08\end{array}$ & $\begin{array}{l}\text { - Introduzir os pressupostos } \\
\text { das leis } 10.639 / 03 \text { e } \\
11.645 / 08 \text { nas aulas de } \\
\text { Ciências/Física. } \\
\text { - Refletir a situação dos } \\
\text { grupos étnicos-raciais na } \\
\text { sociedade e na escola. }\end{array}$ & $\begin{array}{l}\text { - Quadro. } \\
\text { - Roda de Conversa. }\end{array}$ & 40 minutos. \\
\hline
\end{tabular}

\footnotetext{
${ }^{7}$ Momentos didáticos são utilizados neste artigo inspirados nos "três momentos pedagógicos" de Delizoicov, (2008).
} 


\begin{tabular}{|c|c|c|c|c|}
\hline 2 & Astronomia Cultural. & $\begin{array}{l}\text { - Apresentar o conceito de } \\
\text { Astronomia e Cultura. } \\
\text { - Diferenciar ciência de } \\
\text { mito. } \\
\text { - Apresentar o Stellarium e } \\
\text { as diferentes Culturas lá } \\
\text { apresentadas. }\end{array}$ & $\begin{array}{l}\text { - Projetor. } \\
\text { - Stellarium. } \\
\text { - Simuladores. } \\
\text { - Sala de Informática. } \\
\text { - Roda de Conversa. }\end{array}$ & 60 minutos \\
\hline 3 & $\begin{array}{l}\text { Sistema Terrestre. Esfe- } \\
\text { ra Celeste. } \\
\text { Pontos Cardeais. Siste- } \\
\text { ma Horizontal, Equato- } \\
\text { rial e Eclíptico. Latitude } \\
\text { Astronômica. Fases da } \\
\text { Lua. Estações do Ano. } \\
\text { Constelações. Movi- } \\
\text { mento Diário dos As- } \\
\text { tros. }\end{array}$ & $\begin{array}{l}\text { - Introduzir conceitos bási- } \\
\text { cos de Astronomia de Po- } \\
\text { sição. } \\
\text { - Entender o Céu e sua } \\
\text { relação com a Terra. }\end{array}$ & $\begin{array}{l}\text { - Projetor. } \\
\text { - Stellarium. } \\
\text { - Simuladores. } \\
\text { - Sala de Informática. } \\
\text { - Roda de Conversa. }\end{array}$ & 90 minutos. \\
\hline 4 & $\begin{array}{l}\text { Planisfério Afro- } \\
\text { Indígena. Mapa Mundi } \\
\text { Afro-Indígena. Jogo das } \\
\text { Constelações. }\end{array}$ & $\begin{array}{l}\text { - Construir o Planisfério } \\
\text { Afro-Indígena. } \\
\text { - Apresentar o Mapa Mun- } \\
\text { di Afro-Indígena. } \\
\text { - Aplicar o Jogo das Cons- } \\
\text { telações }\end{array}$ & $\begin{array}{l}\text { - Cola. } \\
\text { - Tesoura. } \\
\text { - Cartões. } \\
\text { - Roda de Conversa. }\end{array}$ & 60 minutos. \\
\hline
\end{tabular}

Quadro 2 - Descrição do Momento Didático 1.

\begin{tabular}{|c|c|c|}
\hline $\begin{array}{l}\text { Situação em } \\
\text { Sala de Aula }\end{array}$ & Metodologia & Questões Étnico-Raciais \\
\hline $\begin{array}{l}\text { Primeiro Mo- } \\
\text { mento Didático } \\
\text { (Leis } 10.639 / 03 \\
\text { e } 11.645 / 08 \text { ) }\end{array}$ & $\begin{array}{l}\text { - Roda de conversa. } \\
\text { - Leis } 10.639 / 03 \text { e } \\
11.645 / 08 \text { escritas } \\
\text { no quadro e, den- } \\
\text { tro da roda de } \\
\text { conversa, sugere- } \\
\text { se a discussão do } \\
\text { significado das } \\
\text { mesmas. } \\
\text { - Questionamento } \\
\text { sobre que outras } \\
\text { leis os estudantes } \\
\text { conhecem (suges- } \\
\text { tão: fazer paralelo } \\
\text { com o Estatuto da } \\
\text { Criança e do Ado- } \\
\text { lescente). }\end{array}$ & $\begin{array}{l}\text { - Discutir sobre a variedade de pessoas } \\
\text { (cabelos, rostos, sotaques, cor da pele e } \\
\text { etc.) na sociedade e na escola. Como, em } \\
\text { general, estas pessoas são vistas e repre- } \\
\text { sentadas? } \\
\text { - Questionar sobre como estes grupos são } \\
\text { representados nas mídias. } \\
\text { - Refletir coletivamente sobre a quantida- } \\
\text { de de estudantes negros, negras e indíge- } \\
\text { nas presentes na escola. } \\
\text { - Discutir sobre quantos professores e } \\
\text { professoras da escola são negros, negras } \\
\text { e indígenas. } \\
\text { - Refletir sobre a importância das duas leis } \\
\text { e o impacto das mesmas para a escola e a } \\
\text { vida em sociedade. } \\
\text { - Discutir sobre o que poderia explicar a } \\
\text { sub-representação de negros, negras e } \\
\text { indígenas em Ciências e Física. } \\
\text { - Refletir sobre quais medidas tomaria, } \\
\text { caso pudesse, para aumentar a represen- } \\
\text { tação de grupos étnicos-raciais pouco } \\
\text { presentes em Ciências e em Física. }\end{array}$ \\
\hline
\end{tabular}

Proposta de Avaliação

- Entrevistar professores e professoras negros, negras e indígenas na escola fazendo perguntas sobre a vida e a trajetória deles e delas nas Ciências e em Física.

- Analisar o papel da menina negra cientista no filme Pantera Negra*.

- Buscar, em aulas e livros didáticos de Ciências e Física, palavras indígenas, africanas e/ou afro-brasileiras que fazem parte do vocabulário científico.

- Levantar informações sobre cientistas brasileiros — vivos ou mortos - negros, negras e indígenas, trabalhando em Física e/ou Astronomia no Brasil e no mundo.

* O filme Pantera Negra tem direção de Ryan Coogler, 2018, Estados Unidos, com legendas em Português. 
Quadro 3 - Descrição do Momento Didático 2.

\begin{tabular}{|c|c|c|c|}
\hline $\begin{array}{l}\text { Situação em } \\
\text { Sala de Aula }\end{array}$ & Metodologia & Questões Étnico-Raciais & Proposta de Avaliação \\
\hline $\begin{array}{l}\text { Segundo Mo- } \\
\text { mento Didático } \\
\text { (Astronomia } \\
\text { Cultural) }\end{array}$ & $\begin{array}{l}\text { - Roda de conversa. } \\
\text { - Apresentação, por } \\
\text { Power Point, da dife- } \\
\text { renciação entre Mito, } \\
\text { Ciência, Astronomia, } \\
\text { Astrologia e Astro- } \\
\text { nomia Cultural. } \\
\text { - Apresentação do } \\
\text { Stellarium. } \\
\text { - Apresentação do céu } \\
\text { das diferentes cultu- } \\
\text { ras presentes no Stel- } \\
\text { larium, focando prin- } \\
\text { cipalmente nas cultu- } \\
\text { ras “Ocidental”, Afri- } \\
\text { cana e Indígena Bra- } \\
\text { sileira (Tupi-Guarani } \\
\text { e Tukano). }\end{array}$ & $\begin{array}{l}\text { - Discutir sobre o que é mito e o que é } \\
\text { ciência e como o conceito de ciência } \\
\text { muda ao longo da história. } \\
\text { - Questionar sobre a universalidade da } \\
\text { ciência ocidental. } \\
\text { - Refletir sobre "como" diferentes po- } \\
\text { vos olham para o céu e se relacionam } \\
\text { com o seu dia a dia. } \\
\text { - Abordar o entendimento do significa- } \\
\text { do histórico da Astrologia que, nos } \\
\text { dias atuais, é considerada pseudociên- } \\
\text { cia. } \\
\text { - Discutir sobre a Ciência e a Física } \\
\text { como culturas ocidentalizadas, com- } \\
\text { postas majoritariamente por homens } \\
\text { brancos. Por que isso acontece? } \\
\text { - Refletir sobre quais são os elementos } \\
\text { envolvidos na construção do “céu" das } \\
\text { culturas ocidental, indígena e africana } \\
\text { abordadas na sequência didática. }\end{array}$ & $\begin{array}{l}\text { - Escrever, em uma página, } \\
\text { um mito que foi contado na } \\
\text { infância e que remeta à As- } \\
\text { tronomia Cultural. } \\
\text { - Criar um conto científico } \\
\text { envolvendo histórias afro- } \\
\text { brasileiras e indígenas. } \\
\text { - Criar novas constelações e } \\
\text { contar as suas próprias his- } \\
\text { tórias. }\end{array}$ \\
\hline
\end{tabular}

Quadro 4 - Descrição do Momento Didático 3.

\begin{tabular}{|c|c|c|c|}
\hline $\begin{array}{l}\text { Situação em } \\
\text { Sala de Aula }\end{array}$ & Metodologia & Questões Étnico-Raciais & Proposta de Avaliação \\
\hline $\begin{array}{l}\text { Terceiro Mo- } \\
\text { mento Didático } \\
\text { (Conceitos bási- } \\
\text { cos de Astrono- } \\
\text { mia de Posição) }\end{array}$ & $\begin{array}{l}\text { - Roda de conversa. } \\
\text { - Apresentação, por } \\
\text { Power Point, de } \\
\text { conceitos básicos } \\
\text { de Astronomia de } \\
\text { Posição (ver Qua- } \\
\text { dro 1) } \\
\text { - Descrição das } \\
\text { similarida- } \\
\text { des/diferenças en- } \\
\text { tre as constelações } \\
\text { nas diferentes cul- } \\
\text { turas. } \\
\text { - Estudo dos eixos e } \\
\text { planos astronômi- } \\
\text { cos fundamentais, } \\
\text { notações, símbolos } \\
\text { e conceitos usados } \\
\text { no estabelecimento } \\
\text { das constelações } \\
\text { nas diferentes cul- } \\
\text { turas. }\end{array}$ & $\begin{array}{l}\text { - Discutir sobre o papel de diferentes } \\
\text { culturas ao longo da história para cul- } \\
\text { minar no arcabouço teórico e geomé- } \\
\text { trico do céu "ocidental". } \\
\text { - Diferenciar os elementos físicos e } \\
\text { simbólicos presentes em cada cultura } \\
\text { estudada. } \\
\text { - Discutir semelhanças e diferenças nas } \\
\text { "constelações" das diferentes culturas } \\
\text { estudadas. } \\
\text { - Refletir sobre como as leis } 10.639 \text { e } \\
\text { 11.645, ao ser discutidas nas aulas de } \\
\text { Ciências e de Física, podem ajudar } \\
\text { docentes a entender que os diferentes } \\
\text { saberes africanos e indígenas extrapo- } \\
\text { lam a comida, a estética e aspectos } \\
\text { religiosos e culturais. }\end{array}$ & $\begin{array}{l}\text { - Contrastar, matematicamente } \\
\text { e geometricamente, os siste- } \\
\text { mas de referência horizontal e } \\
\text { equatorial com o sistema ter- } \\
\text { restre de localização, definin- } \\
\text { do cada medida angular dos } \\
\text { sistemas. } \\
\text { - Visualizar, no Mapa Mundi } \\
\text { Afro-Indígena, as diferentes } \\
\text { culturas estudadas descreven- } \\
\text { do em que regiões do mundo } \\
\text { elas se encontram e quais } \\
\text { eram seus hábitos baseando- } \\
\text { se na sua cultura estelar. } \\
\text { - Escrever as semelhanças e } \\
\text { diferenças que mais se desta- } \\
\text { cam na comparação das } \\
\text { constelações presentes no } \\
\text { Stellarium. }\end{array}$ \\
\hline
\end{tabular}


Quadro 5. Descrição do Momento Didático 4.

\begin{tabular}{|c|c|c|c|}
\hline $\begin{array}{l}\text { Situação em } \\
\text { Sala de Aula }\end{array}$ & Metodologia & Questões Étnico-Raciais & Proposta de Avaliação \\
\hline $\begin{array}{l}\text { Quarto Mo- } \\
\text { mento Didáti- } \\
\text { co (Planisfério, } \\
\text { Mapa Mundi } \\
\text { Afro-Indígena } \\
\text { e Jogo das } \\
\text { Constelações) }\end{array}$ & $\begin{array}{l}\text { - Roda de conversa. } \\
\text { - Apresentação, por } \\
\text { Power Point, do } \\
\text { Planisfério, Mapa } \\
\text { Mundi Afro- } \\
\text { Indígena e do Jogo } \\
\text { das Constelações. } \\
\text { - Semi-montagem } \\
\text { do Planisfério Ce- } \\
\text { leste com as cons- } \\
\text { telação Africana e } \\
\text { Indígena Brasileira. } \\
\text { - Montagem do } \\
\text { Jogo das Constela- } \\
\text { ções }\end{array}$ & $\begin{array}{l}\text { - Discutir sobre como as diferen- } \\
\text { tes culturas se distribuem no } \\
\text { mundo. } \\
\text { - Elaborar pontos de intersecção } \\
\text { entre as diferentes culturas. } \\
\text { - Discutir as semelhanças e } \\
\text { diferenças nas "constelações" } \\
\text { das diferentes culturas estuda- } \\
\text { das. }\end{array}$ & $\begin{array}{l}\text { - Relatar, em roda, o impacto dos } \\
\text { quatro momentos didáticos e a } \\
\text { contribuição da intervenção para } \\
\text { a sua formação. } \\
\text { - Discorrer, em texto escrito, sobre } \\
\text { a situação dos negros, negras e } \\
\text { indígenas na Educação Básica e } \\
\text { na ciência brasileira. Como a si- } \\
\text { tuação mudaria se o Brasil tivesse } \\
\text { tido um outro processo histórico? } \\
\text { - Explicar como o céu pode nos } \\
\text { contar diferentes histórias sobre } \\
\text { os povos ao longo da história e } \\
\text { como estas histórias podem nos } \\
\text { ajudar a compreender a ciência } \\
\text { como um processo humano que } \\
\text { depende da história, do tempo e } \\
\text { da sociedade. } \\
\text { - Dissertar sobre a contribuição de } \\
\text { africanos, afro-brasileiros e indí- } \\
\text { genas para a construção do co- } \\
\text { nhecimento. }\end{array}$ \\
\hline
\end{tabular}

\section{IV.2 Os Momentos Didáticos}

Os quatro Momentos Didáticos foram pensados para proporcionar aos professores de Ciências/Física uma oportunidade ímpar de, usando Astronomia Cultural, tecnologias e outros materiais didáticos em sala de aula, discutir conceitos de Física e Astronomia, mas, principalmente, fomentar a discussão crítica sobre como as relações étnico-raciais se dão no campo da história, da educação e das instituições, tornando quase nula, por exemplo, a presença de negras, negros e indígenas como cientistas e principalmente em áreas como Física e Astronomia. É preciso, acima de tudo, aproveitar a SD para questionar a ordem (ainda que invisível) e apresentar as tensões étnico-raciais como temas centrais do debate, questionando os porquês de, mesmo o Brasil sendo majoritariamente composto por pessoas negras e pardas, haver tão poucas pessoas deste grupo social trabalhando em ciências de maneira geral, mas, principalmente, nas ciências exatas.

Sugere-se aos professores de ciências que reflitam coletivamente, com os estudantes, quais são as relações de poder envolvidas nas escolhas e nas possibilidades profissionais; sobre o que está por trás da invisibilidade de algumas alteridades (negros, negras e indígenas) na sociedade brasileira e qual é o papel da escola, da família, da sociedade (mídias) e do Estado na manutenção destas subalternidades.

É preciso discutir os racismos institucionais e os entraves que, invisivelmente, dificultam a entrada e a permanência de pessoas negras e indígenas nas ciências, ainda hoje. 
É preciso "descolonizar", como adverte Freire, os discursos vigentes ressaltando que a África é, na verdade, o berço da civilização; que a África não é uma coisa só, um só país. É preciso dizer que já havia civilização na África quando os portugueses lá chegaram no século XV e, mais importante, que já havia ciência desenvolvida na África nesse momento da História (SCHWARCZ; STIRLING, 2015).

É preciso entender e divulgar, por outro lado, que os povos indígenas são variados e que não se pode avançar numa educação que se diz (pelo menos na Lei) preocupada com as questões étnico-raciais se não desconstruir os estereótipos; se seguirmos retratando os indígenas do passado como se estes povos estivessem congelados no tempo. Os indígenas fazem parte do século XXI e assim devem ser tratados e compreendidos pelos não indígenas. A ancestralidade afro-indígena deve ser preservada e não vista como um impedimento à incorporação da "cultura científica ocidental", vista como apenas uma outra cultura, nem melhor e

nem pior. É preciso descolonizar os currículos e levar a discussão das relações étnico-raciais para as salas de aula e para as aulas de Ciências/Física, em todos os níveis da educação brasileira.

\section{IV.3 Os céus}

Na presente SD, o céu é entendido e discutido como o lugar dos fenômenos celestes que têm inspirado, por milênios, todas as civilizações que já passaram pela Terra. As observações sistemáticas dos fenômenos celestes é que levam ao desenvolvimento da Física (PIRES, 2008). Ao longo da história há uma direta relação - observacional, mitológica, cultural, religiosa, econômica, revolucionária e científica - do ser humano com o céu. Esta perspectiva do direito do ser humano de todas as etnias e de todos os lugares de observar o céu e entender que o mesmo está repleto de histórias, que são diversas, deve perpassar os currículos da Educação Básica para que se consiga desenvolver uma pedagogia social da diferença, crítica e reflexiva por natureza. É preciso despertar nos estudantes dos diferentes níveis de educação uma cosmovisão alicerçada pelo respeito à diferença. As histórias contadas e descritas no céu são nesta SD usadas como um mecanismo pedagógico, um caminho de possibilidades. Estas histórias podem ser usadas para discutir a construção histórica e social do conhecimento e as inter-relações dos conceitos científicos, entendendo a construção do conhecimento como localizado espacialmente e temporalmente. A ciência, como construção humana e histórica é, portanto, transitória, e o céu materializa didaticamente esta visão. A SD também propõe que a partir dos estudos das constelações vistas em diferentes culturas haja, em sala de aula, o diálogo e a troca de saberes entre as várias disciplinas - Física, Matemática, Filosofia, História, Geografia (meio ambiente), entre outras. Trata-se de ir muito mais além dos limites de uma disciplina, ou de, simplesmente, discutir conceitos técnicos de Astronomia. Há nas histórias "contadas" no céu uma riqueza didática simbólica que precisa ser explorada por professores em sala de aula. O céu (ou os céus, melhor dizendo) é um incentivo capaz de fomentar a curi- 
osidade de estudantes, curiosidade esta que deve ser, para o bem da cultura científica, preservada ao longo de todo o percurso da educação (básica e superior) dos indivíduos.

\section{IV.4 As culturas estudadas}

Como já se pôde notar, usamos na presente proposta, por vezes, a palavra "cultura" como referência às diferentes constelações vistas por diferentes povos na Terra e que estão representadas no Stellarium (CECILIO JUNIOR, 2016). Desta forma, neste trabalho, o termo "constelação" é definido como padrão cultural de um certo povo. É como diferentes povos enxergam no céu, ao longo do tempo, os padrões estelares. Denominamos "Cultura Ocidental" como sendo as constelações definidas oficialmente pela União Astronômica Internacional que, no céu inteiro, considerando o Hemisfério Norte e Sul celeste, somam 88 constelações. Estas 88 constelações são vistas, guardadas as limitações de observação local, por qualquer pessoa no Planeta Terra. É como se o céu tivesse sido loteado, em diferentes tamanhos e, nesse caso, o termo "constelação" significa muito mais do que simplesmente um agrupamento de estrelas que forma figuras no céu, como erroneamente sugerem muitos livros didáticos de ciências (LANGHI; NARDI, 2007). Há, em uma constelação, diferentes objetos astronômicos (estrelas, galáxias, nebulosas, planetas, etc.) já que esta corresponde a um loteamento do céu onde estes objetos aparecem projetados. As estrelas, por exemplo, de uma constelação não estão todas à mesma distância física do observador; esta sensação é reforçada apenas por conta das grandes distâncias envolvidas e que separam as estrelas do observador (no referencial "Terra"). As estrelas podem, assim, estar fisicamente ou angularmente muito distantes uma das outras numa dada constelação. Para os Tupi-Guaranis, por exemplo, manchas claras e escuras no céu também são denominadas de "constelações". No Apêndice mostram-se algumas janelas do Stellarium e oferece-se algumas indicações de como operá-lo.

Noticia-se que há poucas culturas africanas e brasileiras representadas no Stellarium. Visando compreender as relações da humanidade com o céu, também em frações não observáveis da esfera celeste no Hemisfério Sul, optamos por expandir nosso estudo aos nativos de outros continentes. O que se busca mostrar é que há diferentes interpretações para uma mesma constelação dadas por povos geograficamente e temporalmente afastados entre si. Desta forma, a escolha das diferentes constelações (a partir de diferentes culturas) foi baseada nos seguintes critérios: as culturas Tupi-Guarani e Tukano são as únicas culturas essencialmente brasileiras disponíveis no Stellarium; Astecas, Navaja, Dakota/Lakota/Nakota e Inuítes são as civilizações nativas de outras regiões do continente americano, que são interessantes para comparação; a cultura Lapônica entra como representante da Astronomia Cultural nativa do norte Europeu e, a Egípcia, como base da cultura estelar africana, única do continente africano a estar disponível no Stellarium.

Vale frisar que as diferentes constelações das diferentes culturas representadas no Stellarium não representam e nem esgotam, de forma alguma, a diversidade de constelações presentes em povos de uma mesma cultura, mas que estão espalhados em diferentes lugares 
da Terra. Por exemplo, pode haver, mesmo dentro da cultura Tupi-Guarani, diferentes registros de constelações dependendo de onde a cultura está localizada. Como não há imagens artísticas disponíveis para o céu do Egito no Stellarium, o mesmo foi constituído na presente proposta a partir da elaboração de materiais didáticos da literatura. As 88 constelações oficiais da União Astronômica Internacional são categorizadas como Austrais (localizadas no Hemisfério Celeste Sul), Boreais (localizadas no Hemisfério Celeste Norte), Zodiacais (que são atravessadas pela eclíptica, localizadas próximas dos limites entre os Hemisférios Celestes Norte e Sul), Equatoriais (que são atravessadas pelo Equador Celeste) e Circumpolares Norte e Sul (as que estão localizadas próximo aos Pólos Norte e Sul Celeste).

\section{IV.5 Materiais didáticos e pedagógicos desenvolvidos}

Como parte da proposta, diferentes materiais didáticos foram desenvolvidos visando explorar, em sala de aula, a Astronomia Cultural no contexto das relações étnico-raciais. Todo o material será disponibilizado eletronicamente como parte de um Recurso Digital (em breve estará disponível no CREF, Centro de Referência do Ensino de Física, da UFRGS).

(i) Apresentação Powerpoint: Trata-se de uma apresentação didática preparada em Powerpoint onde os conteúdos apresentados no Quadro 1 são minuciosamente detalhados, representados e discutidos seguindo os referenciais teóricos adotados na presente Sequência.

(ii) Planilhas comparativas das culturas: Quadros "resumo" onde os nomes de origem das constelações exploradas e o equivalente em Português são mostrados. O quadro apresenta ainda o equivalente das constelações "estrangeiras" na cultura Ocidental e seus significados na cultura estudada. As informações foram retiradas de variados artigos e textos da literatura disponíveis no Stellarium (ver Seção IV.4 deste artigo para as referências).

Quadro 6 - Cultura estelar Tupi-Guarani.

\section{TUPI-GUARANI}

\section{Língua Na- Português Relação com o Céu Significado tiva Ocidental}

\begin{tabular}{|c|c|c|c|}
\hline Tapi’i & Anta do Norte & $\begin{array}{l}\text { Cefeu. Lagarto e Cassi- } \\
\text { opéia }\end{array}$ & $\begin{array}{l}\text { Primavera. Caminha sobre o Caminho da } \\
\text { Anta (Via Láctea) }\end{array}$ \\
\hline Eixu & Vespeiro & Plêiades & Início do ano Tupi-Guarani \\
\hline Tuivaé & Homem-velho & Touro e Órion & $\begin{array}{l}\text { Verão para o Sul e chuva para o Norte. } \\
\text { Conta a lenda que uma mulher traiu seu } \\
\text { marido (o homem-velho) cortando-lhe a } \\
\text { perna. Os deuses, com pena, transforma- } \\
\text { ram-no em uma constelação. }\end{array}$ \\
\hline $\begin{array}{l}\text { Tupi'i rai- } \\
\text { nhykã }\end{array}$ & Queixada da Anta & Hyades & Chegada da Chuva \\
\hline
\end{tabular}




\begin{tabular}{|l|l|l|l|}
\hline Joykexo & $\begin{array}{l}\text { Joelho do homem- } \\
\text { velho }\end{array}$ & Cinturão de Órion & $\begin{array}{l}\text { Representa uma linda mulher, símbo- } \\
\text { lo de fertilidade }\end{array}$ \\
\hline $\begin{array}{l}\text { Guirá } \\
\text { Nhandu }\end{array}$ & Ema & $\begin{array}{l}\text { Cruzeiro do Sul, Escor- } \\
\text { pião. Mosca. Centauro. } \\
\text { Triângulo Austral }\end{array}$ & Inverno para o Sul seca para o Norte \\
\hline Veado & Veado & $\begin{array}{l}\text { Vela. Cruzeiro do Sul. } \\
\text { Carina e Centauro }\end{array}$ & Outono \\
\hline
\end{tabular}

Quadro 7 - Cultura estelar Tukano.

\section{TUKANO}

\section{Língua Nati- Português \\ va \\ Relação com o Céu Significado Ocidental}

\begin{tabular}{|l|l|l|l|}
\hline Mhuã & Jacundá & Aquário & Fevereiro \\
\hline Dahsiu & Camarão & Aquário & Fevereiro \\
\hline Yaí & Onça & Cassiopéia e Perseu & Março e Abril \\
\hline Nohkoatero & Grupo de Estrelas & Plêiades & Abril \\
\hline Waikhasa & Jurai de peixes & Hyades & Abril e Maio \\
\hline Sioyahpu & Cabo de enxó & Órion & Maio \\
\hline Yhe & Garça & Cabeleira de Berenice & Agosto e Setembro \\
\hline Aña & Jararaca & Escorpião e Sagitário & Setembro, Outubro e Novembro \\
\hline Pamô & Tatu & Águia e Golfinho & Dezembro \\
\hline
\end{tabular}

Quadro 8-Cultura estelar Asteka.

\section{Língua Nati- Português Relação com o Céu Significado \\ va}

\begin{tabular}{|l|l|l|l|}
\hline Mamalhuaztli & O novo fogo & $\begin{array}{l}\text { Cinturão e bainha de } \\
\text { Órion }\end{array}$ & $\begin{array}{l}\text { Vara utilizada para acender fogueiras em } \\
\text { cerimônias religiosas. }\end{array}$ \\
\hline Tianquiztli & O mercado & Plêiades & $\begin{array}{l}\text { Um conjunto de mercadorias, como um } \\
\text { mercado. }\end{array}$ \\
\hline Citlaltlachtl & $\begin{array}{l}\text { O jogo de bola } \\
\text { das estrelas }\end{array}$ & Gêmeos & $\begin{array}{l}\text { Religioso. Representa o movimento do Sol } \\
\text { e da Lua nos céus. }\end{array}$ \\
\hline Xonecuilli & O pé torto & Ursa Menor & $\begin{array}{l}\text { Entidade religiosa doente e pobre que se } \\
\text { sacrifica para se tornar o Deus do Sol. }\end{array}$ \\
\hline Citlalcolotl & $\begin{array}{l}\text { A face do Es- } \\
\text { corpião }\end{array}$ & Escorpião & Indefinido \\
\hline
\end{tabular}


Quadro 9 - Cultura estelar Dakota/Nakota/Lakota.

DAKOTA/NAKOTA/LAKOTA

\begin{tabular}{|c|c|c|c|}
\hline Língua Nativa & Português & $\begin{array}{l}\text { Relação com o Céu Ociden- } \\
\text { tal }\end{array}$ & Significado \\
\hline Nape & Mão & Órion & Indefinido \\
\hline Mato Tipila & Obrigo do Urso & Gêmeos & Indefinido \\
\hline Gleska Wakan & Círculo sagrado & Círculo do inverno & Indefinido \\
\hline Tayamni & Búfalo & Órion. Cão Maior e Plêiades. & Indefinido \\
\hline Wiçincala Sakowin & Sete Garotas & Plêiades & Indefinido \\
\hline Oçeti/Peta & Bola de Fogo & Leão & Indefinido \\
\hline Tun win & Mulher azul & Big Dipper & Indefinido \\
\hline Wakinyan & O pássaro trovão & Ursa Menor & Indefinido \\
\hline Agleska & Salamandra & Cisne & Indefinido \\
\hline Keya & Tartaruga & Pegasus & Indefinido \\
\hline Hehaka & Alce & Peixes & Indefinido \\
\hline Cansasa Pusyapi & Salgueiro vermelho seco & Áries, Triângulo Austral & Indefinido \\
\hline Zuzeca & Serpente & Cão Maio & Indefinido \\
\hline
\end{tabular}

Quadro 10 - Cultura estelar Intuíte.

\section{INTUÍTE}

\begin{tabular}{|c|c|c|c|}
\hline Língua Nativa & Português & $\begin{array}{ll}\text { Relação } & \text { com } \\
\text { o Céu Oci- } \\
\text { dental }\end{array}$ & Significado \\
\hline Aagjuuk & Dois raios de Sol & Águia & Medição do tempo \\
\hline Akkuttujuuk & $\begin{array}{l}\text { Dois minutos afasta- } \\
\text { dos }\end{array}$ & Órion & Retorno da luz do Sol ao ártico \\
\hline Qimmitt & Cães & Touro & $\begin{array}{l}5 \text { cães que caçam Nanook, o urso } \\
\text { polar }\end{array}$ \\
\hline Quturjuuk & Clavículas & $\begin{array}{l}\text { Gêmeos e } \\
\text { Cocheiro }\end{array}$ & Indefinido \\
\hline
\end{tabular}




\begin{tabular}{|c|c|c|c|}
\hline Pituaq & Pira & Cassiopéia & Fornece a luz \\
\hline Uqsuutaattiaq & Recipiente de gordura & Cassiopéia & Armazena o combustível da pira \\
\hline Tukturjuit & Rena & Ursa Maior & Indefinido \\
\hline Sivulliik & Dois em frente & Boleiro & $\begin{array}{l}\text { Um menino correndo de um avô } \\
\text { enfurecido }\end{array}$ \\
\hline Kingulliq & Aquela que está atrás & Lira & $\begin{array}{l}\text { A avó que persegue o menino e o } \\
\text { avô }\end{array}$ \\
\hline Sakiattiak & Esterno & Plêiades & Indefinido \\
\hline Nuuttuittuq & Nunca se move & Polaris & Indefinido \\
\hline Ullaktut & Corredores & $\begin{array}{l}\text { Cinturão de } \\
\text { Órion }\end{array}$ & Caçadores de Nanook perdidos \\
\hline Qangimmaarik & Sobrinhos(as) & $\begin{array}{l}\text { Nebulosa de } \\
\text { Órion }\end{array}$ & Grupo de crianças \\
\hline Aviguti & $\mathrm{O}$ divisor & Via Láctea & Divide o céu \\
\hline Sikuliaqsiujuittuq & $\begin{array}{l}\text { Nome de um homem } \\
\text { assassino }\end{array}$ & Procyon & Indefinido \\
\hline
\end{tabular}

Quadro 11 - Cultura estelar Lapônica.

\section{LAPÔNICA}

\section{Língua Nativa Português $\quad$ Relação com o $\quad$ Significado \\ Céu Ocidental}

\begin{tabular}{|l|l|l|l|}
\hline Sarva & Alce & $\begin{array}{l}\text { Cocheiro, } \\
\text { Cassiopéia }\end{array}$ & $\begin{array}{l}\text { Constelação dominante. Relacionada à caça } \\
\text { pré domesticação das renas }\end{array}$ \\
\hline Favdna & Caçador & Acturus & Principal caçador de Sarva \\
\hline Fauna davgge & Arco e flecha & Ursa Maior & Arma utilizada por Favdna para matar Sarva \\
\hline Boahjenaste & Escora do céu & Polaris & $\begin{array}{l}\text { Se Favdna, em sua caça, acertar acidental- } \\
\text { mente a Escora do céu, conta a lenda o } \\
\text { mundo chegará ao fim }\end{array}$ \\
\hline Galla & Ajudante & Procyon & Ajudante de Favdna em sua caça \\
\hline Gallbameck & Filhos de Galla & Cinturão de Órion & Mais auxiliares na grande caça \\
\hline Cuiogahaegjek & Os esquiadores & Castor e Polux & Ajudante de Favdna \\
\hline Rougot & Matilha de cães & Plêiades & Auxiliares na caça por Sarva \\
\hline
\end{tabular}


Quadro 12 - Cultura estelar Egípcia.

\section{EGÍPCIA}

\section{Língua Nati- Português} va

\begin{tabular}{|c|c|c|c|}
\hline spdt & Triângulo & Sírius e cabeça Cão Maior & Indefinido \\
\hline $\mathrm{s} 3 \mathrm{~h}$ & $\underline{\text { Sah }}$ & Órion e Lebre & Indefinido \\
\hline 'rt & Mandíbula & Aglomerado de Híades (Touro) & Indefinido \\
\hline h3w & Rebanho & Plêiades & Indefinido \\
\hline $\mathrm{kd}$ & Redil para ovelhas & Cabeça da Baleia & Indefinido \\
\hline $3 \mathrm{pd}$ & Pássaro & Triângulo e Perseus & Indefinido \\
\hline `ryt & Duas mandíbulas & Cassiopéia & Indefinido \\
\hline wi3 & Barco & Capricórnio & Indefinido \\
\hline srt & Ovelha & Grou & Indefinido \\
\hline Indefinido & Peixe Khanuwy & Patas de sagitário & Indefinido \\
\hline Indefinido & Proa & Escorpião & Indefinido \\
\hline htp rdwy & Sek & Hidra Fêmea. Sextante e Taça & Indefinido \\
\hline $\mathrm{m} 3 \mathrm{i}$ & Leão & Leão & Indefinido \\
\hline $3 n(w)$ & Hórus & $\begin{array}{l}\text { Patas da Ursa Maior, Leão menor. Cães de caça. } \\
\text { Cabeleira de Berenice e Rabo do Lice. }\end{array}$ & Indefinido \\
\hline mnit & Poste de Amarração & Estrelas: Acturus. Alkaid e Muphrid. & Indefinido \\
\hline mshtyw & $\begin{array}{l}\text { Perna dianteira do Tou- } \\
\text { ro }\end{array}$ & Corpo da Ursa Maior & Indefinido \\
\hline rrt & Hipopótamo & Corpo da Ursa Maior & Indefinido \\
\hline $3 \mathrm{st} \mathrm{d} 3 \mathrm{mt}$ & Crocodilo & Hércules & Indefinido \\
\hline $\mathrm{d} 3 \mathrm{t}$ & Balsa & Estrelas: Naos e Regor (Popa) & Indefinido \\
\hline sb3w nw mw & Estrela d'Água & Centro do Câncer (M44) & Indefinido \\
\hline ws3ty bk3ty & Duas gêmeas & Cruzeiro do Sul & Indefinido \\
\hline knmt & Cow & Cão Maior & Indefinido \\
\hline $\operatorname{sb} 3 w y$ & Par de Estrelas & Cebeças dos gêmeos & Indefinido \\
\hline nwt & A nós/Avelã da deusa & Via Láctea & Indefinido \\
\hline
\end{tabular}

\section{Relação com o Céu Ocidental Significado}


(iii) Planisfério ou Carta Celeste Afro-Indígena: Os Planisférios, também denominados de Mapa ou Carta Celeste, são excelentes ferramentas didáticas, pois materializam a partir de uma certa localização na Terra o céu observado por uma certa cultura numa certa época do ano. Conceitos como latitude astronômica, que é equivalente à latitude geográfica, podem também ser explorados, já que nem todas as pessoas localizadas na Terra verão o mesmo céu. Os Planisférios (Fig. 1 e 2) são mapas giratórios onde, nas bordas, encontram-se doze divisões que representam os doze meses do ano. Portanto, a partir da escolha de data e hora e da identificação do Polo Sul Celeste na esfera celeste, o observador pode vislumbrar o mesmo céu que vê presencialmente todas as noites. Visando envolver os estudantes parcialmente na confecção de um planisfério celeste, usando papel, tesoura e cola, propomos a montagem parcial de um Planisfério adaptado a disponibilizar o céu da cultura Egípcia (constelação africana), Navajo (constelação indígena americana) e das culturas Tupi-Guarani e Tukano (constelações indígenas-brasileiras) conforme "arte" disponível no Stellarium. A nossa carta celeste contém 50 constelações de quatro diferentes culturas presentes no céu noturno do Hemisfério Sul ao longo do ano. Os estudantes poderão apreciar constelações como a Ema, Homem-Velho, Hipopótamo, Crocodilo, Mhua, Pamõ, Lagarto, entre outras constelações afrobrasileiras e indígenas que são encontradas neste planisfério celeste e que sobreviveram ao tempo para eternizar a história e a cultura desses povos. O Planisfério pode ainda ser usado para discutir, em sala de aula, como a aparência do céu noturno é mutável ao longo do ano devido ao movimento de revolução da Terra em torno do Sol e como este parece caminhar, aparentemente, entre as estrelas ao fundo do espaço. Este movimento, que também explica parcialmente as estações do ano, define constelações características de cada estação do ano Leão no céu do outono (março); Escorpião no céu do inverno (junho); Pégasus no céu de primavera (setembro) e Órion no céu de verão (dezembro).

À esquerda e direita, respectivamente, na Fig. 1, apresentamos um modelo da vista frontal e traseira do Planisfério. As peças são parcialmente montadas em sala de aula junto com os estudantes. Um texto informativo sobre o funcionamento do planisfério bem como informações acerca do projeto "Astronomia nas Culturas" são também disponibilizados. Na Fig. 2, que apresenta os detalhes de algumas das constelações indígenas (esquerda) e africanas (direita) estudadas, o ponto central das cartas equivale ao Polo Sul Celeste, extensão do Polo Sul Terrestre na Esfera Celeste; a presença do Equador Celeste e da Eclíptica dão uma ideia aproximada das posições relativas de cada asterismo; as constelações das diferentes culturas flutuam por entre estrelas de referência, como Sírius, Canopus e Antares, facilmente identificadas a "olho nu". E sobre o "céu", prende-se uma "capa" rotativa, contendo horários de 0h a 24h em suas bordas, cuja combinação de data e hora apresenta o céu noturno naquele instante para o Brasil. Para encontrar a representação da cultura estelar corretamente em uma certa data e hora do ano, basta segurar o Planisfério com a mão, sobre a cabeça, fazendo alinhar o ponto central desta com o Polo Celeste em questão e, com a outra mão, girar o disco até fazer 

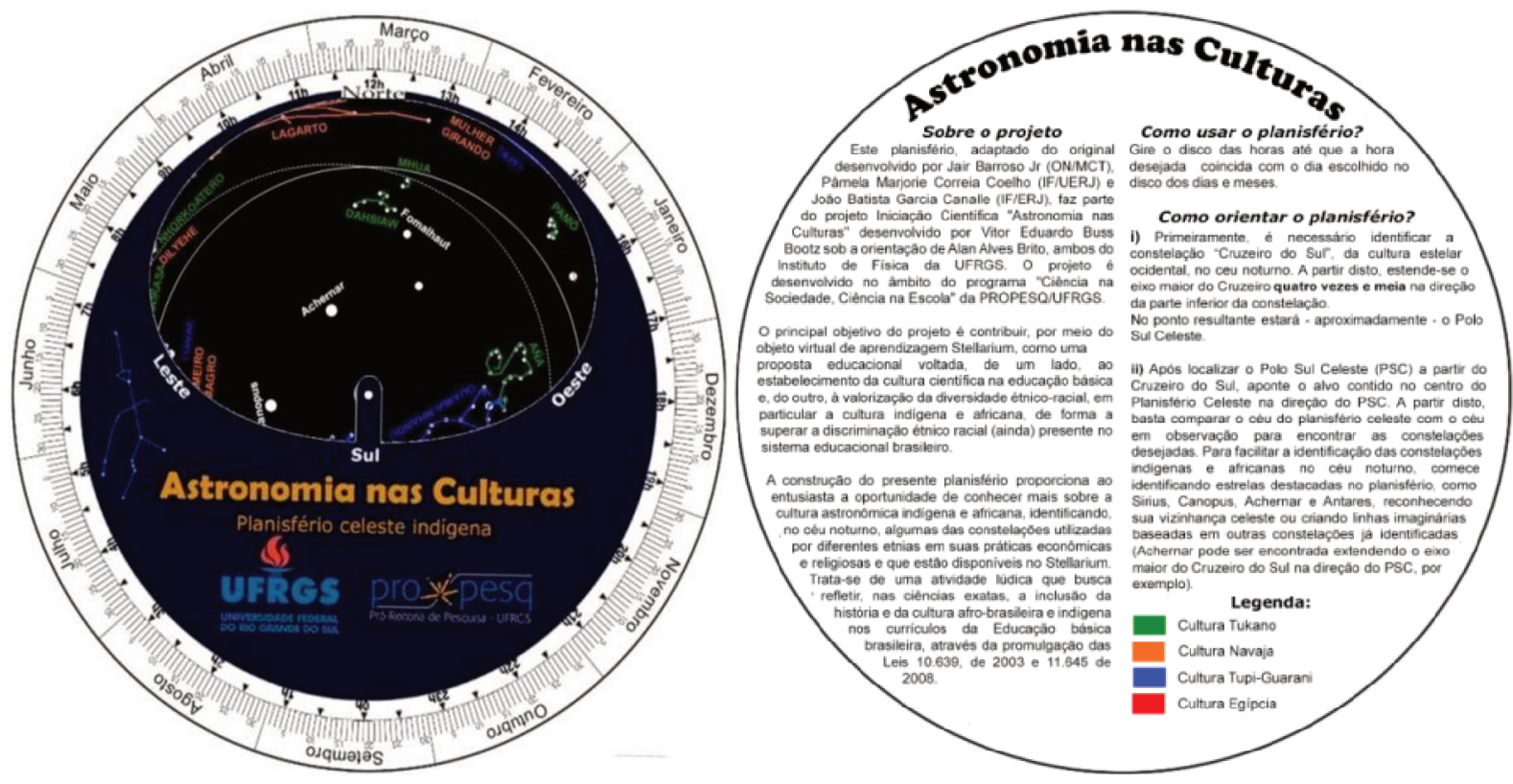

Fig. 1 - Vista frontal e traseira do Planisfério Afro-Indigena, modelo inspirado no disponível no sítio oficial da Olimpíada Brasileira de Astronomia e Astronáutica.
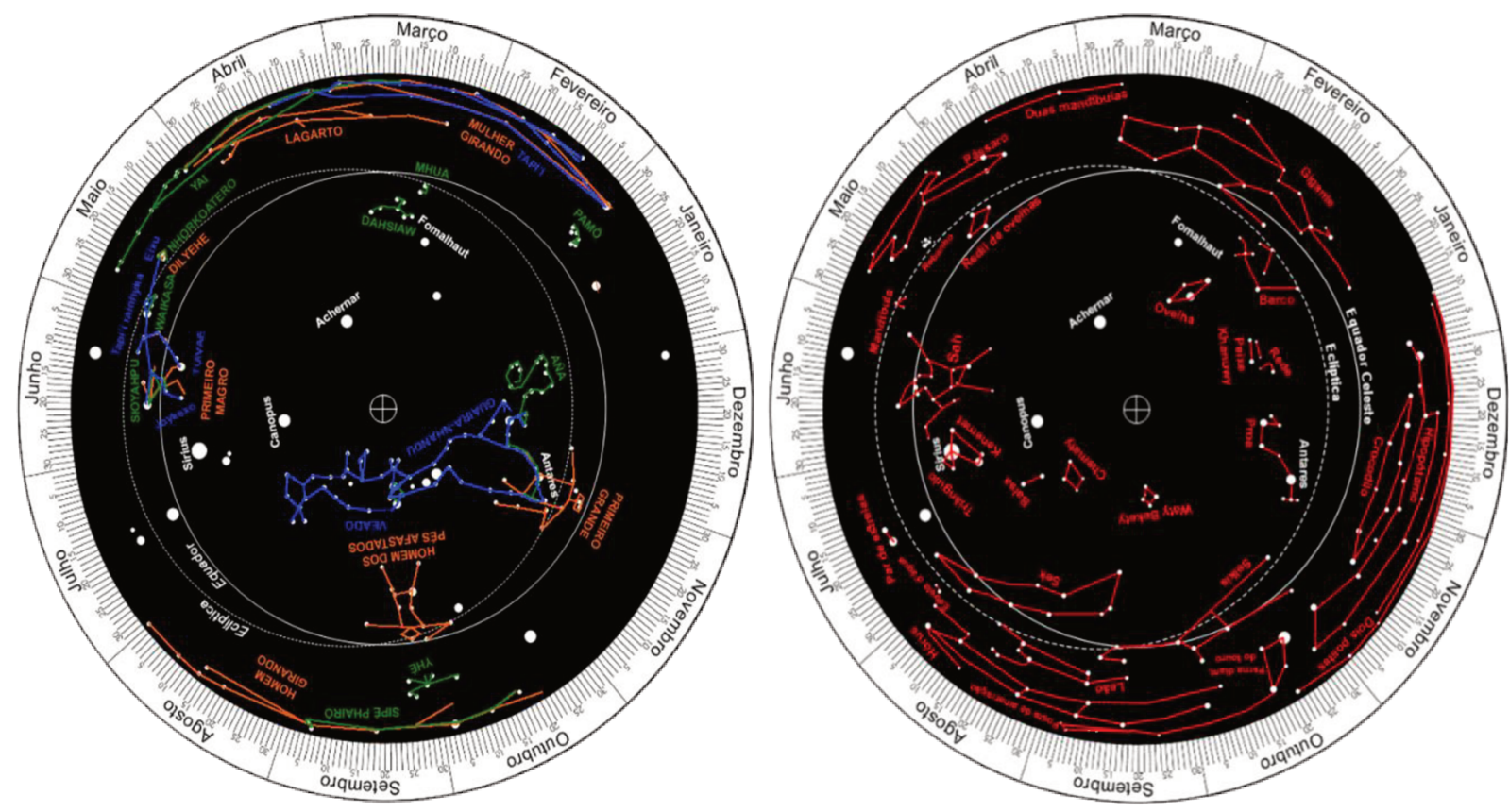

Fig. 2 - Vista detalhada da cultura estelar Tupi-Guarani, Tukano e Navaja (à esquerda, em azul, verde e laranja respectivamente) e Egípcia (à direita, em vermelho).

coincidi-lo com as referências corretas de data do mês e hora. Todos os conceitos básicos voltados a Astronomia de Posição devem ser antes apresentados e discutidos no Stellarium. 
(vi) Mapa Mundi Afro-Indígena: Finalizado o Planisfério Celeste Afro-Indígena, sentimos a necessidade de contextualizar a cultura astronômica de cada povo com sua localização sobre o globo terrestre, juntamente de uma explicação sucinta da cultura estelar para que, possivelmente, se pudesse determinar os motivos que levaram uma civilização específica a possuir/construir um certo conjunto de "constelações". A exemplo da astronomia Lapônica, do norte europeu, seu conjunto de asterismos representa um grupo de caçadores perseguindo um alce, enquanto que nas culturas astronômicas sul-americanas as constelações retratam, em geral, a fauna e flora brasileira com constelações como o Veado, a Anta, a Ema, entre outros. Para tanto, utilizando o software gratuito e mapa interativo Google MyMaps, desenhamos regiões sobre uma imagem do mapa-mundi que podem ser analisadas em sala de aula e cujo interior possui uma breve explicação da cultura estelar da civilização em questão, junto de detalhes importantes de cada constelação, retirados de quadros semelhantes ao apresentado no Quadro 7. Este mapa, apresentado na Fig. 3, pode ser acessado por todo e qualquer estudante, ou professor, ou interessado que possua o link de compartilhamento, bem como editado e complementado pelos usuários. Esta ferramenta interativa ajuda a ressignificar os saberes e ampliar os conhecimentos acerca das constelações apresentadas.
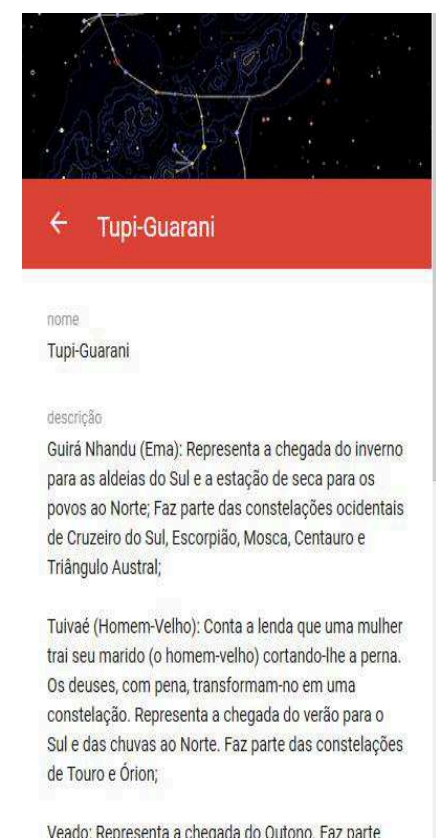

Veado: Representa a chegada do Outono. Faz parte

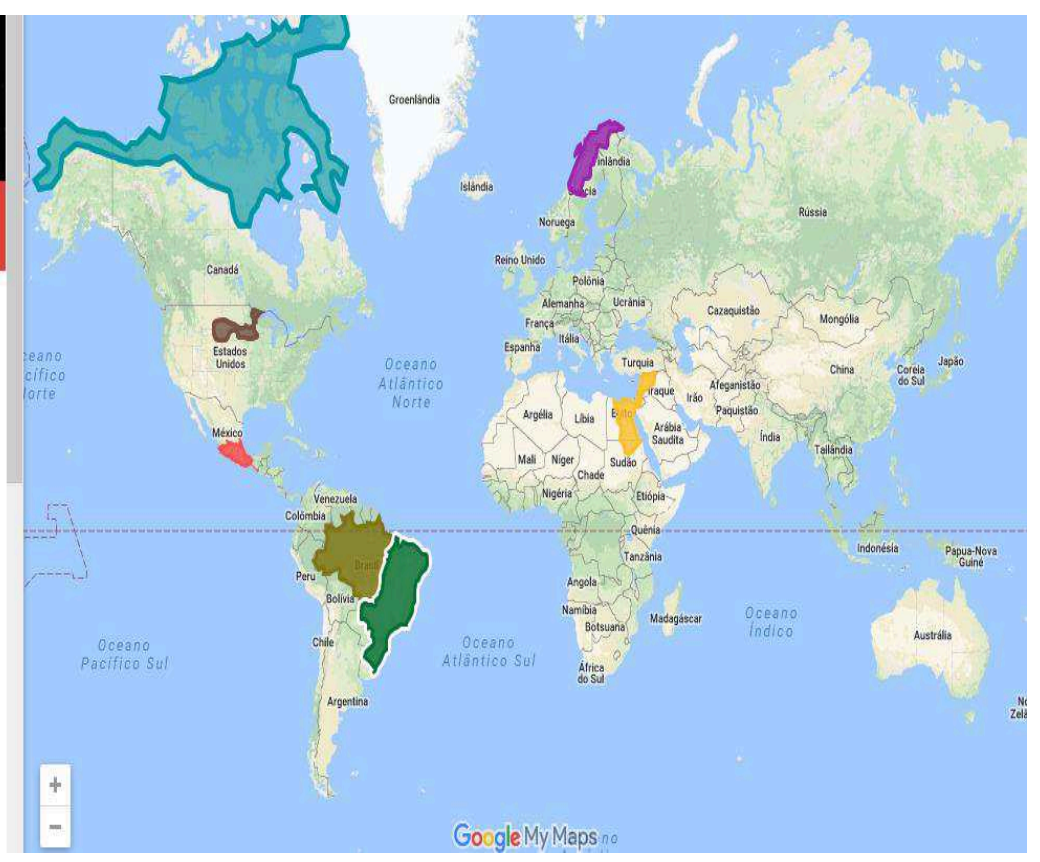

Fig. 3 - Mapa interativo Google MyMaps contendo a localização geográfica aproximada dos diferentes povos estudados pelo projeto, junto a textos e imagens referentes à sua cultura estelar.

(v) Jogo das Constelações: E, por fim, desenvolvemos o Jogo das Constelações (Fig. 4), que é um jogo de palavras cruzadas. Os estudantes são separados em grupos com o objetivo de encontrar, num certo intervalo de tempo, o máximo possível de nomes de conste- 
lações das diferentes culturas estudadas. Trata-se de uma oportunidade adicional para discutir o sentido e o significado das diferentes culturas na história.

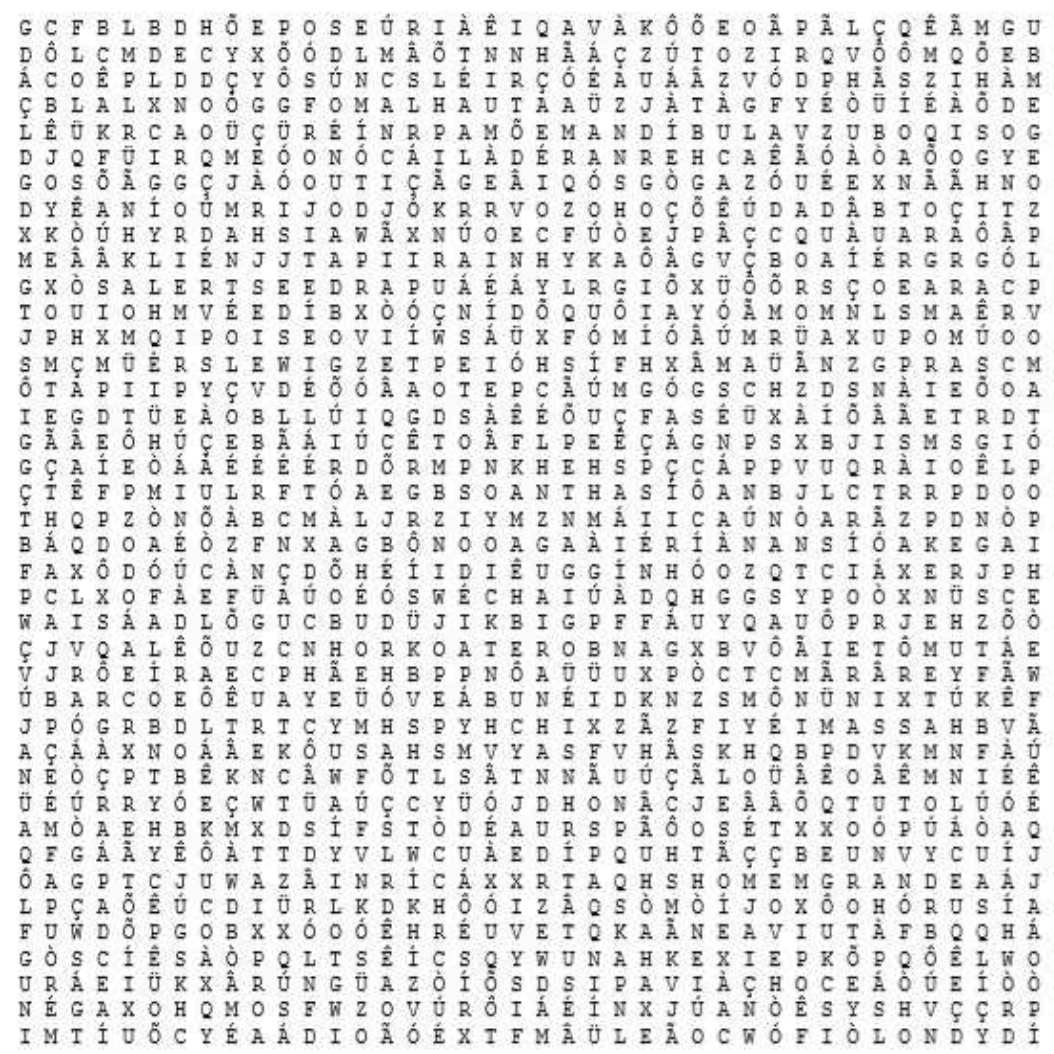

Fig. 4 - Caça-palavras com nomes das constelações indígenas e africana.

\section{IV.6 Uma experiência em sala de aula}

Como já explicado, a Sequência Didática foi concebida no âmbito da formação inicial e continuada de professores de Ciências, bem como para fundamentar a formação descolonizada dos currículos da Educação Básica. Parte da mesma foi aplicada em uma escola da rede pública do município de Porto Alegre, a Escola Municipal de Ensino Fundamental Jean Piaget, em abril de 2018. A escola está localizada em um bairro de alta vulnerabilidade social. Trabalhando em três turnos (manhã, tarde e noite), a escola atende pouco mais de 1000 alunos, espalhados em três turmas de Educação Infantil, onze turmas de I Ciclo (crianças de 6-8 anos de idade), dez turmas de II Ciclo (crianças entre 9-11 anos), oito turmas de III Ciclo (entre 12-14 anos) e sete turmas de EJA (Educação de Jovens Adultos). Isto se deve a que o sistema público do município de Porto Alegre é ciclado, isto é, constituído por ciclos, cada um abrangendo três anos.

Nessa aplicação, que se estendeu por duas (2) horas e 30 minutos, houve a participação de 19 estudantes (dez meninos e nove meninas), acompanhados por dois professores da Educação Fundamental com formação em Ciências e em Geografia; a Coordenadora Pedagó- 
gica, formada em Pedagogia; uma estagiária do curso de Licenciatura em Filosofia e dois professores com formação em Física/Astronomia (autores deste artigo).

Das atividades propostas neste artigo, apenas a apresentação em Powerpoint e o Mapa Mundi Afro-Indígena ficaram de fora nesta aplicação, em função do tempo disponibilizado pela escola para o encontro ser reduzido (seriam necessários mais encontros cobrindo duas semanas, aproximadamente). Preferencialmente preferimos a roda de conversa e a exploração do Stellarium, em que destacamos os conceitos chave de Astronomia e a montagem e explicação do Planisfério.

$\mathrm{Na}$ roda de conversa, que envolveu professores e estudantes, focamos os seguintes temas: Leis 10.639/03 e 11.645/08, cultura e história afro-brasileira e indígena, Astronomia e a concepção do céu noturno diversificado e multicultural. Em seguida, os estudantes foram separados em quatro equipes; cada equipe confeccionou um planisfério celeste rotativo. Ao término da montagem procedeu-se à explicação sobre seu funcionamento e utilidade prática, culminando o encontro numa atividade cooperativa de busca de palavras, o Jogo da Constelações (Fig. 8), ou seja, cada equipe deveria encontrar o maior número de constelações possíveis, as quais estavam presentes no céu de cada planisfério por eles confeccionado, promovendo a investigação do mesmo e reforçando o conhecimento de constelações, tópico que os estudantes nunca tinham estudado na escola.

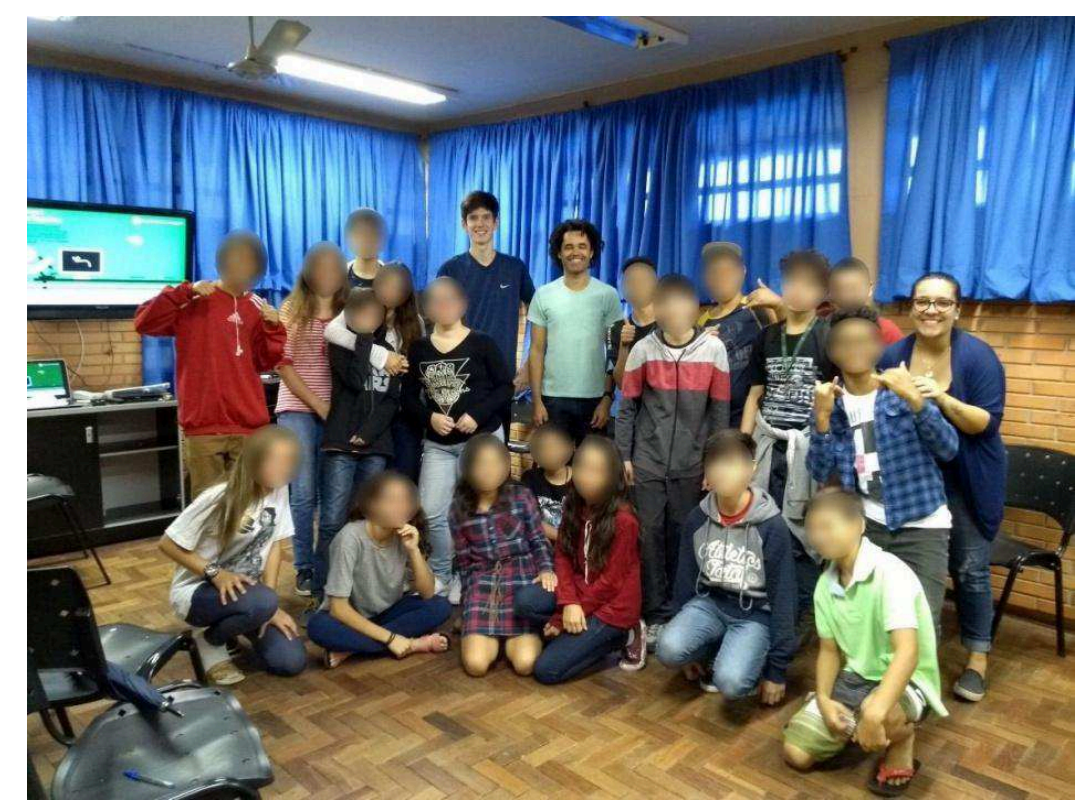

Fig. 5 - Aplicação do projeto Astronomia Cultural na Escola Municipal Jean Piaget de Porto Alegre, abr. 2018.

Nossa observação indicou que mesmo alunos considerados pelos professores tímidos, apáticos e/ou indiferentes no dia a dia escolar, mostraram-se motivados e grandemente integrados e participativos na realização da atividade. Pode-se ter uma noção, através da Fig. 5 , do clima que foi possível construir em sala de aula. Notamos também que os professores, a 
coordenadora pedagógica, a estagiária e os estudantes dessa escola que participaram da atividade desconheciam as Leis 10.639/03 e 11.645/08, que é um dos focos da presente proposta. Os estudantes mostraram-se atentos a todos os temas discutidos, participando ativamente com perguntas, dúvidas e falas. É importante destacar que dois estudantes da escola, um menino e uma menina, são tidos por professores como "guris pouco participativos", mas, para a nossa surpresa, ambos estiveram muito envolvidos nas atividades propostas.

Destaca-se que não apresentamos aqui uma análise sistemática das implicações da $\mathrm{SD}$, embora o engajamento dos estudantes mostrasse que ela é motivadora, pois análises metodologicamente suportadas estão sendo realizadas pelo grupo de pesquisa, sendo que não era o objetivo aqui apresentá-las. Contudo, com base em perguntas, falas e expressões dos alunos e em pequenos relatos escritos dos estudantes, bem como na avaliação dos professores e estagiária, foi possível inferir que os resultados da SD são bastante positivos e que ela consegue colocar em discussão questões étnico-raciais, de gênero, etc.

É importante noticiar que os professores, ainda que norteados por diferentes referenciais pedagógicos, teóricos ou epistemológicos, nos diversos níveis da Educação Brasileira podem adaptar a proposta, discutindo os diferentes aspectos astronômicos como apresentado nos quatro momentos didáticos (Quadros 1 a 5) e questões das relações étnico-raciais como convier a seus contextos. Podem, inclusive, aplicar parte da proposta ou aplicá-la em etapas, mas sem perder de vista que o objetivo é "descolonizar" o currículo, divulgar e discutir as Leis, mostrar e discutir o céu nas diferentes culturas na busca de uma formação para a cidadania, mais atuante e transformadora.

A discussão que conseguimos promover teve o sentido de, a todo momento, fundamentar a divulgação e a efetivação das Leis em sala de aula como um "campo de poder", articulado às premissas dos currículos, que acabam por produzir significado social. Houve preocupação de incitar os estudantes a pensarem o próprio currículo escolar como parte de uma cultura e como sendo instrumento e prática construídos histórica e socialmente. Desta forma, a cultura Ocidental (a ciência hegemônica) foi interpretada como apenas mais uma cultura e que, portanto, apresenta com seus signos e significados fortemente articulados às disputas de poder (OGAWA, 1986). A linguagem da ciência hegemônica é, por si só, uma expressão de poder de um grupo cultural.

Falar da cultura indígena e africana em sala de aula é, também, reconhecer que há outras culturas que precisam ser abarcadas nos currículos oficiais; é reconhecer que estas diferentes culturas têm suas ferramentas, signos e significados próprios para o ensinar e o aprender; que as alteridades precisam ser valorizadas em sala de aula (etnocentricidade europeia versus o "outro") e que o "saber fazer" é bem localizado. Qual é a cultura hegemônica? Como ela é estabelecida? Por que silenciar as outras culturas? O que é ciência? É preciso existir o binarismo (ciência versus não ciência)? Em resumo, a aplicação brevemente relatada aqui foi executada em sala de aula de maneira a refletir o conceito de "reciprocidade" nas diferentes 
culturas, capaz de incorporar, modificar e ampliar as possibilidades de compreensão do(s) mundo(s).

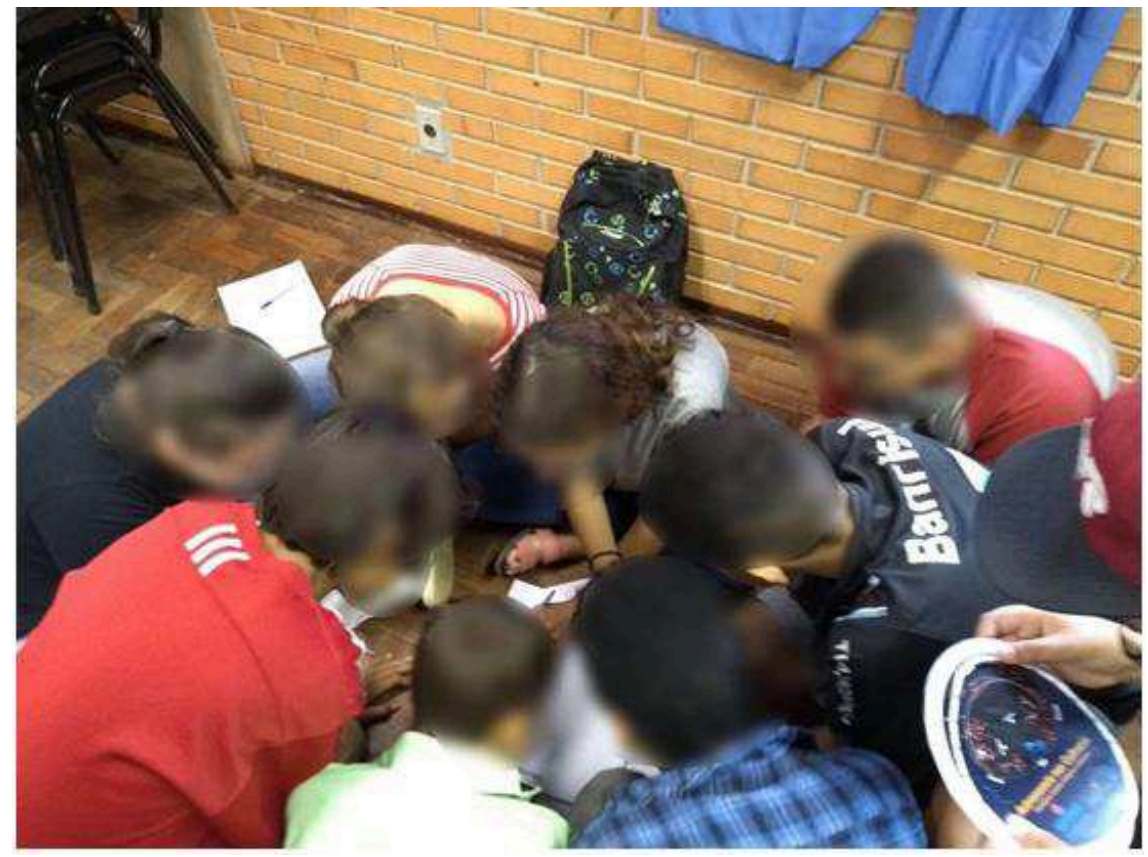

Fig. 6 - Estudantes da Escola Municipal Jean Piaget executando, em conjunto, a atividade proposta, que consiste na procura dos nomes das constelações presentes nos planisférios em um grande caça-palavras. Um dos estudantes manipula o Planisfério.

\section{Considerações finais}

A Constituição Brasileira, em seu Art. 205, e a LDB não deixam dúvidas sobre qual é o papel dos diferentes órgãos e instituições de ensino, em todos os níveis de educação, quando se trata de ações voltadas para as questões étnico-raciais. Tendo este pressuposto em mente, o presente artigo apresenta uma SD constituída de diferentes atividades que podem ser executadas e discutidas em sala de aula, nas aulas de Ciências/Física da Educação Básica, para fazer valer políticas públicas de Estado criadas para valorizar a contribuição de africanos, afro-brasileiros e indígenas à História e à Cultura do Brasil. Em particular, o céu em diferentes culturas (“Ocidental”, Indígena e Africana) é aqui apresentado e contextualizado na visão pós-crítica do ensino.

Espera-se, que ao final do processo os estudantes sejam incitados a dialogar e a pesquisar junto à sua comunidade (pais, avós, líderes comunitários, etc.) como o céu noturno é percebido e interpretado (especialmente em comunidades de afrodescendentes, quilombolas, indígenas) fazendo com que a escola gere nesses estudantes e seus familiares um sentimento de pertencimento, de valorização das suas culturas. Ao mesmo tempo, espera-se que, levados pela curiosidade epistêmica, na acepção de Freire, os estudantes (e a comunidade) adquiram o gosto pelo conhecimento científico, articulando seus saberes com aqueles hoje aceitos pela comunidade científica, os modelos cosmológicos e as explicações do nosso Universo. 
Uma maneira interessante de observar e estudar o céu noturno, não a única, é aprendendo a navegar e a investigar o Stellarium (como dissemos, em breve um tutorial explicativo do funcionamento de cada ferramenta a partir de textos e vídeos intuititvos, bem como a sugestão de atividades para a utilização dos objetos de ensino, estará no CREF do Instituto de Física da UFRGS) o que junto a esta SD, espera-se que contribua, como um material didático útil aos professores, estudantes e promotores culturais na diminuição dos preconceitos e posturas discriminatórias nos ambientes formais e não formais de ensino, incorporando novos paradigmas e metodologias à práxis em educação científica. Esta $\mathrm{SD}$, com seus referenciais teóricos, não é uma construção absoluta. Alternativamente, como dito, ela pode ser adaptada e ressignificada conforme as realidades e as demandas dos usuários. Além disso, a proposta alinha-se às recomendações dos PCNs (BRASIL, 1997; 1998) quanto uso de tecnologias na educação científica. Aproveitamos, assim, o vasto acervo bibliográfico no software gratuito Stellarium focado em Astronomia Cultural para elaborar este material didático-pedagógico tendo como princípio a interatividade dos estudantes com a informação, de modo que estes possam aprender brincando e compartilhar o conhecimento através de atividades cooperativas. Busca-se, ao fim e ao cabo, a descolonização dos currículos das ciências exatas. Como salienta Munanga (2003), a pedagogia antirracista é construída a partir de temas multiculturais voltados, na educação, para a identidade racial e a diversidade cultural.

\section{Referências}

ALBUQUERQUE et al. Astronomia e Cultura nas Pesquisas em Ensino de Ciências na Última Década. I Simpósio Nacional de Educação em Astronomia, Atas... Rio de Janeiro, 2011. Disponível em: <https://www.researchgate.net/publication/268056531>. Acesso em: 4 ago. 2018.

ARAÚJO, D. C. C.; VERDEAUX, M. F. S.; CARDOSO, W. T. Uma proposta para a inclusão de tópicos de astronomia indígena brasileira nas aulas de Física do Ensino Médio. Ciência \& Educação, Bauru, v. 23, n. 4, p. 1035-1054, 2017.

ARAÚJO, D. C. C. Uma proposta para a inserção de tópicos de astronomia indígena brasileira no ensino médio: desafios e possibilidades. 185 fl. Dissertação (Mestrado profissional em Ensino de Ciências) - UNB, Brasília, 2014.

BARBA DE PIÑA CHÁN, B. Iconografía mexicana: Las representaciones de los astros. III. Plaza y Valdes, 2002.

BELMONTE, J. A. A celestial map of the ancient Egyptian firmament. BAR International Series, 2003. p. 161-169.

BRASIL. Presidência da República. Casa Civil. Subchefia para Assuntos Jurídicos. Lei no 9.394, de 20 de dezembro de 1996 . 
. Secretaria de Educação Fundamental. Parâmetros curriculares nacionais: ciências naturais - séries iniciais / Secretaria de Educação Fundamental. - Brasília: MEC/SEF, 1997.

. Secretaria de Educação Fundamental. Parâmetros curriculares nacionais: Ciências Naturais 30 e 4 o ciclos /Secretaria de Educação Fundamental. Brasília: MEC / SEF, 1998a.

. Secretaria de Educação Média e Tecnologia. Parâmetros Curriculares Nacionais: ciências naturais (5a a 8a séries). Brasília: Secretaria de Educação Fundamental. MEC/SEF, 1998b. 138 p.

. Ministério da Educação, Secretaria de Educação Média e Tecnológica. Parâmetros Curriculares Nacionais: ensino médio. Brasília: Ministério da Educação. Secretaria da Educação Média e Tecnológica, Ministério da Educação, 1999. 364 p.

PCN+: Ensino médio: orientações Educacionais Complementares aos Parâmetros Curriculares Nacionais: Ciências da Natureza, Matemática e suas tecnologias. Brasília: MEC, SEMTEC, 2002. 144 p.

Diretrizes Curriculares Nacionais para a Educação das Relações Étnico-Raciais e para o Ensino de História e Cultura Afro-Brasileira e Africana. Brasília: Conselho Nacional da Educação, Conselho Pleno, Resolução nº 1, de 17 de junho de 2004.

- Secretaria de Educação do Distrito Federal. Orientações Curriculares - Ensino Fundamental - Séries e Anos Iniciais. 2008a

- Secretaria de Educação do Distrito Federal. Orientações Curriculares - Ensino Fundamental - Séries e Anos Finais. 2008b.

Plano Nacional de implementação das diretrizes curriculares nacionais para educação das relações étnico-raciais e para o ensino de história e cultura afro-brasileira e africana. Ministério da Educação. Secretaria da Educação Continuada, Alfabetização, Diversidade e Inclusão. Brasília: MEC, SECADI, 2013.

Conselho Nacional de Educação. Diretrizes Curriculares Nacionais para a Formação Inicial e Continuada dos Profissionais do Magistério da Educação Básica. Parecer no 2/2015, de 9 de junho de 2015. Brasília, Diário Oficial [da] República Federativa do Brasil, Seção 1, Pág. 13, de 25 de junho de 2015.

CARDOSO, W. T. O Céu dos Tukano na escola Yupuri: construindo um calendário dinâmico. 2007. Tese (Doutorado em Educação Matemática) - PUC, São Paulo. Disponível em: <http://eacultural.fcaglp.unlp.edu.ar/base/Walmir\%20Cardoso/Tese-Walmir\%20Thoma zi\%20Cardoso.pdf>. Acesso em: 04 ago. 2018. 
CARDOSO, W. T. Astronomia Cultural: como povos diferentes olham o Céu. e-Boletim da Física, v. 5, n. 5, 2016. Disponível em: <http://periodicos.unb.br/index.php/ebfis/article/view/21372/15314>. Acesso em: 4 ago. 2018.

CECILIO JUNIOR, E. P. Stellarium: aprendendo astronomia com software. 1. ed. Curitiba: Appris, 2016.

CHILDREY, D. Star Trails Navajo: A Different Way to Look at the Night Sky. Victoria: BC, Canada: Trafford Publishing, 2004.

DANTAS, C. R. S. Avaliação no ensino de ciências no nível fundamental: investigando orientações oficiais e práticas docentes, fazendo "escuta" e intervenções em escolas. 2017. Tese (Doutorado) - Instituto de Física, UFRGS, Porto Alegre.

DELIZOICOV, D. La Educación en Ciencias y la Perspectiva de Paulo Freire. Alexandria Revista de Educação em Ciência e Tecnologia, v. 1, n. 2, p. 37-62, 2008.

FARES, E. et al. O universo das sociedades numa perspectiva relativa: exercícios da etnoastronomia. Revista Latino-Americana de Educação em Astronomia, São Carlos, n. 1, p. 77 85, 2004.

FERNANDES, E; CINEL, N. C. L. B.; LOPES, V. N. Da África aos indígenas do Brasil: caminhos para o estudo de História e Cultura Afro-brasileira e Indígena. 1. ed. Porto Alegre: UFRGS, 2016.

FORQUIN, J. C. Escola e Cultura: As bases sociais e epistemológicas do conhecimento escolar. Porto Alegre: Artes Médicas, 1993.

FREIRE, P. Educação Como Prática da Liberdade. Rio de Janeiro: Paz e Terra, 1967. Pedagogia do Oprimido. 17. ed. Rio de Janeiro: Paz e Terra, 1987.

Pedagogia da Autonomia: saberes necessários à prática educativa. Rio de Janeiro: Paz e Terra, 1996.

GARCIA, C. S. et al. "As coisas do céu": etnoastronomia de uma comunidade indígena como subsídio para a proposta de um material paradidático. Revista Latino-Americana de Educação em Astronomia, São Carlos, n. 21, p. 7-30, 2016.

GOMES, N. L. Indagações sobre currículo: diversidade e currículo [Nilma Lino Gomes]; (orgs.) Jeanete Beauchamp, Sandra Denise Pagel, Aricélia Ribeiro do Nascimento. Brasília: Ministério da Educação, Secretaria de Educação Básica, 2007.

IBGE. Síntese de indicadores sociais: uma análise das condições de vida da população brasileira: 2017/IBGE. Coordenação de População e Indicadores Sociais. Rio de Janeiro: IBGE, 2017. 
JAFELICE, L. C. Abordagem antropológica: educação ambiental e astronômica desde uma perspectiva intercultural. In: JAFELICE, L. C. (Org.). Astronomia, educação e cultura: abordagens transdisciplinares para os vários níveis de ensino. Natal: Editora UFRN, 2010. Cap. 4, p. 213-426.

JAFELICE, L. C. Astronomia cultural nos ensinos fundamental e médio. Revista LatinoAmericana de Educação em Astronomia, São Carlos, n. 19, p. 57-92, 2015.

JUNIOR, P. L.; OSTERMANN, F.; REZENDE, F. Liderança e Gênero em um debate acadêmico entre graduandos em Física. Revista Brasileira de Pesquisa em Educação em Ciências, v. 10, n. 1, 2011a.

JUNIOR, P. L.; REZENDE, F.; OSTERMANN, F. Diferenças de gênero nas preferências disciplinares e profissionais de estudantes de nível médio: relações com a educação em ciências. Ensaio Pesquisa em Educação em Ciências, v. 13, n. 2, 2011 b.

LANGHI, R.; NARDI, R. Ensino de Astronomia: erros conceituais mais comuns presentes em livros didáticos de ciências. Caderno Brasileiro de Ensino de Física, v. 24, n.1, p. 87-111, 2007.

LANGHI, R.; NARDI, R. Educação em Astronomia: repensando a formação de professores. São Paulo: Escrituras Editora, 2012.

LEE, A. S.; ROCK, J.; O’ROURKE, C. Dakota/Lakota Star Map Constellation Guidebook: An introduction to D(L)akota Star Knowledge. Native Skywatchers, 2014.

LIMA, B. S.; BRAGA, M. L. de S.; TAVARES, I. Participação das mulheres nas ciências e tecnologias: entre espaços ocupados e lacunas. Revista Gênero, v. 16, n. 1, 2015.

LIMA, F. P. et al. Astronomia indígena: relações céu-terra entre os indígenas no Brasil: distintos céus, diferentes olhares. In: MATSUURA, O. T. (Org.). História da astronomia no Brasil (2013). Recife: CEPE, v. 1, p. 87-131, 2014. Disponível em: <http://site.mast.br/ HAB2013/historia_astronomia_1.pdf>. Acesso em: 01 mai. 2018.

LOPEZ, A. Astronomía, Identidad y Cambio en comunidades mocovíes del Chaco Argentino. Dissertação em Antropologia. 2001. Argentina.

LUNDMARK, B. Sol-och månkult samt astrala och celesta föreställningar bland samerna (Culto do Sol e da Lua e conceitos astrais e celestiais entre os lapões). ISSN 0347-8114, Editora Västerbottens läns hembygdsförening, 1982.

MACDONALD, J. The arctic sky: inuit astronomy, star lore, and legend. Toronto, Ontario: The Royal Ontario Museum and the Nunavut Research Institute, 1998. 
MENEZES, D. et al. A física da UFSC em números: evasão e gênero. Caderno Brasileiro de Ensino de Física, v. 35, n. 1, p. 324-336, 2018.

MUNANGA, K. Uma abordagem conceitual das noções de raça, racismo, identidade e etnia. Palestra proferida no $3^{\circ}$ Seminário Nacional Relações Raciais e Educação-PENESBRJ, em 05 nov. 2003.

OGAWA, M. Toward a new rationale of science education in a non-western society. European Journal of Science Education, v. 8, n. 2, p. 113-119, 2017.

OLIVEIRA FILHO, K.; SARAIVA, M. F. Astronomia \& Astrofísica. São Paulo. Editora da Física, 2014.

PIRES, A. S. T. Evolução das Ideais da Física. São Paulo: Editora Livraria da Física, 2008.

ROSA, K. Science identity possibilities: a look into Blackness, masculinities, and economic power relations. Cultural Studies of Science Education, 2018a.

ROSA, K. Racismo Ambiental, 2018b. Disponível em: <https://racismoambiental.net.br/ 2018/05/10/negro-nao-tem-que-falar-so-sobre-raca-defende-professora/>. Acesso em: 4 ago. $2018 b$.

SANTANA, R. S.; FARIAS, L. M. S.; REBELO-PINTO, F. A Lei 11.645/08 e o modelo epistemólogico dominante: em busca de ecologias para a cosmogonia iorubá no ensino de História. Revista da Associação Brasileira de Pesquisadores/as Negros/as (ABPN), [S.1.], v. 9, n. 22, p. 49-65, jun. 2017. ISSN 2177-2770. Disponível em: $<$ http://www.abpnrevista.org.br/revista/index.php/revistaabpn1/article/view/395>. Acesso em: 03 mai. 2018.

SANTOS, A. C. F. You Don’t Look Like a Physicist. The Physics Teacher, v. 55, 2017.

SILVA, T. T. Documentos de Identidade: Uma introdução às teorias do currículo. Belo Horizonte: Autêntica, 1999.

WOLF, A. et al. Stellarium. Disponível em: <http://www.stellarium.org>. Acesso em: 08 mar. 2018.

SCHWARCZ, L.; STARLING, H. M. Brasil: uma Biografia. São Paulo: Companhia das Letras, 2015.

\section{Apêndice}

Na sequência, visando facilitar o entendimento do Stellarium, são mostradas algumas imagens e explicações sobre as abas de comandos que aparecem no código. 


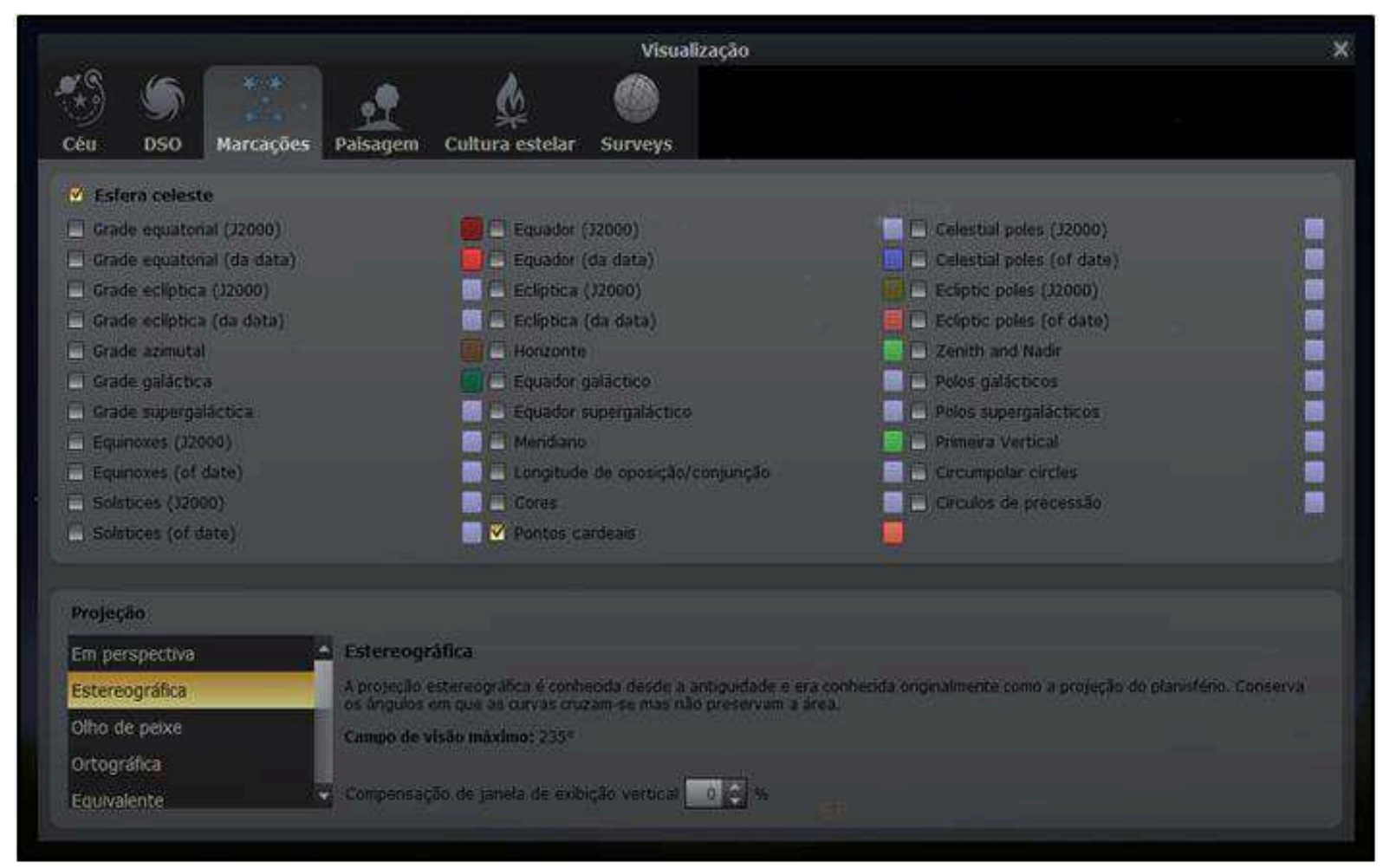

Fig. 7 - Aba Marcações da janela "de opções do céu e de visualização” do Stellarium.

A Fig. 7 mostra a aba Marcações do Stellarium. Os detalhes da aba podem variar de versão para versão do código, mas, de maneira geral, ela possui três seções:

(i) Esfera Celeste: nela os pontos cardeais, linhas e planos importantes como a linha do meridiano, planos fundamentais e grades equatoriais (sistema equatorial de referência), eclíptica (sistema eclíptico de referência ou plano que contém o círculo que representa a órbita da Terra) e azimutal (sistema horizontal de referência) podem ser controlados e exibidos no céu. Estas linhas e grades são cruciais para o posicionamento e localização dos objetos no céu, segundo os preceitos da cultura Ocidental.

(ii) Constelações: esta seção exibe (liga e desliga) as linhas (perímetros) das constelações presentes nas diferentes culturas, bem como exibe os nomes (rótulos) e a arte (imagens) se for o caso, de cada uma delas.

(iii) Projeção: estas técnicas de projeção são úteis já que permitem visualizar o céu, que tem simetria esférica, na tela do computador. Não é trivial representar em duas dimensões uma "componente" (o céu) que é tri-dimensional. Os professores precisam, com seus estudantes, explorar diferentes projeções e fazê-los perceber as diferenças entre elas. Trata-se também de um excelente exercício de visualização geométrica. Além disso, vê-se na Fig. 7 que há a opção de alterar, no Stellarium, a paisagem a ser mostrada (aba Paisagem). 


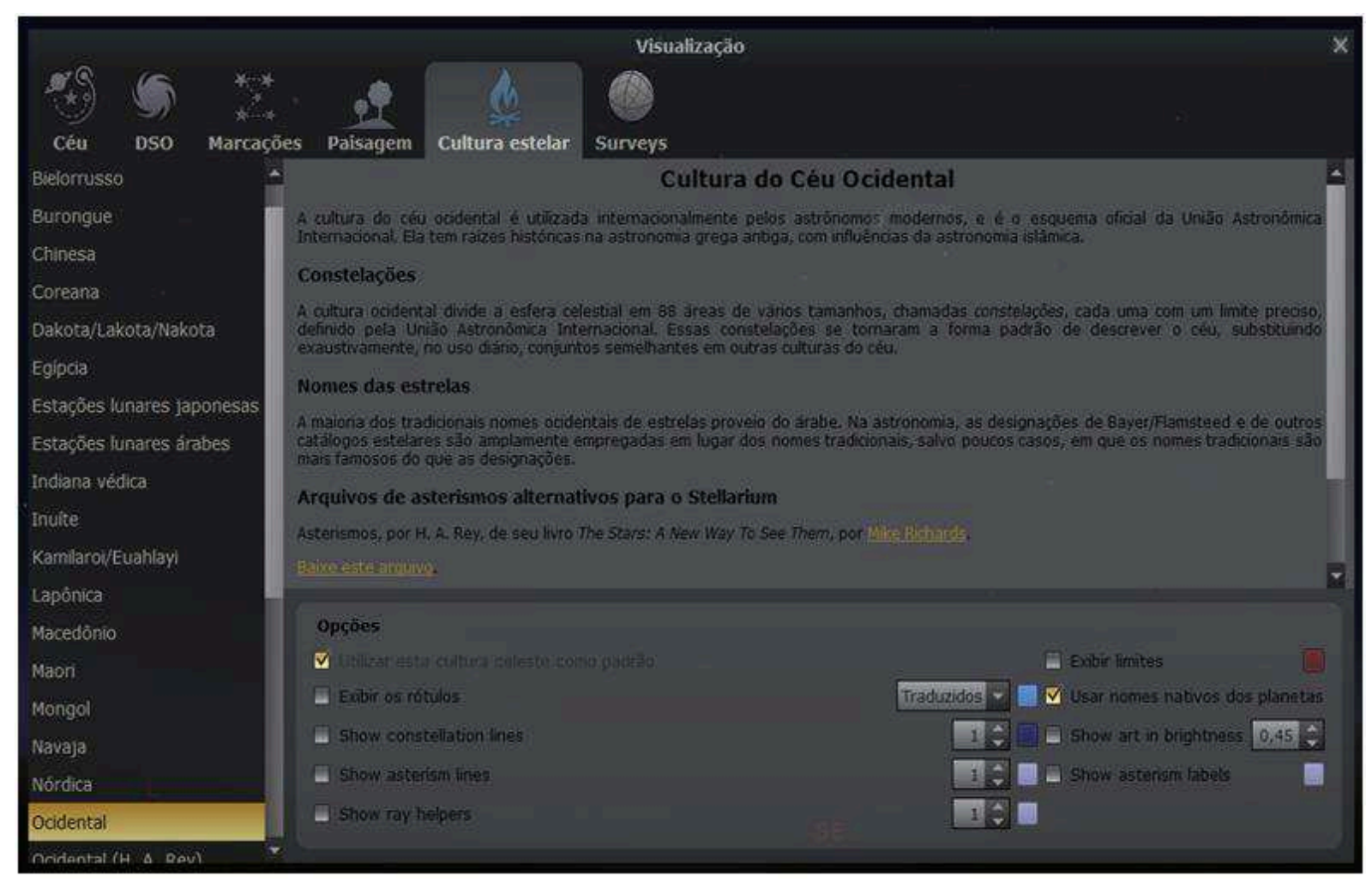

Fig. 8 - Aba Cultura Estelar da janela "de opções do céu e de visualização" do Stellarium. Em algumas versões do código esta aba pode também ser denominada de Mitologia.

Na Fig. 8, vê-se que se pode escolher, no Stellarium, diferentes padrões culturais (constelações) por meio de uma lista onde a "cultura Ocidental" é a cultura "default", isto é, a cultura ocidental é o padrão que aparece no código, mas o estudante pode escolher qualquer outra cultura ali disponível. Ao escolher a cultura Árabe, por exemplo, os estudantes poderão visualizar o que os Árabes enxergavam no céu, pelo menos o que o Stellarium registra como sendo o céu dessa cultura a partir da investigação e contribuições de diferentes pesquisadores. Os nomes e a arte das constelações, como já foi explicado, podem também ser exibidas (quando há arte disponível).

A Fig. 9 apresenta uma simulação feita no Stellarium, em perspectiva, do céu de Porto Alegre para a cultura Asteca. 


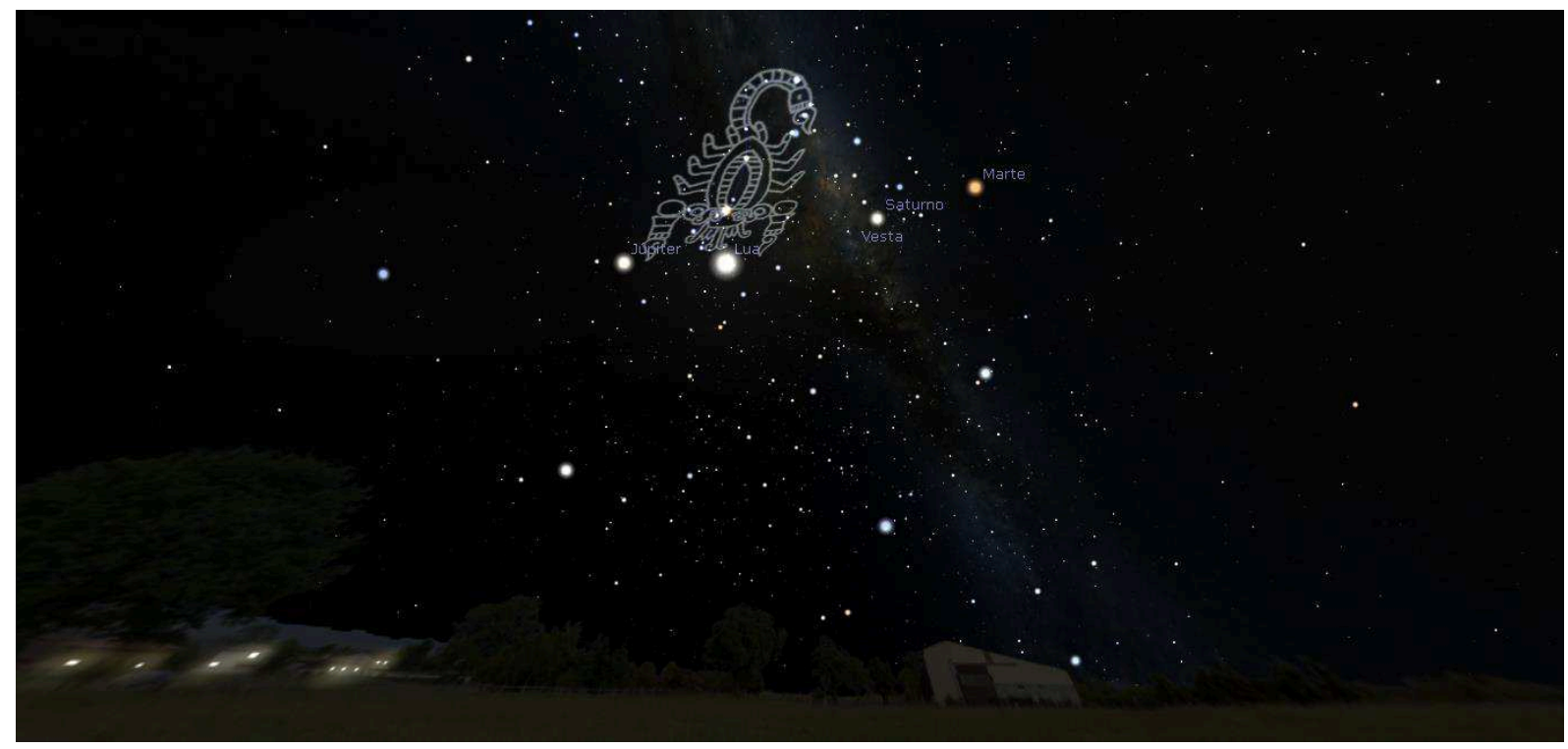

Fig. 9 - Mostra a simulação celeste em perspectiva e feita no Stellarium exibindo a constelação "A face do Escorpião", da cultura Asteca, em conjunção com a Lua, Saturno, Júpiter e Marte para um observador em Porto Alegre no dia 30 de abril de 2018.

Dentre as 31 opções de civilizações e culturas presentes no Stellarium (civilizações ocidentais, orientais, atuais ou já extintas), escolhemos 11 civilizações representativas para estudar (Fig. 10):

- Tupi-Guarani (ver artigo disponível eletronicamente ${ }^{8}$ ).

- Tukano (Cardoso 2007).

- Astecas (Barba de Piña Chán 2002).

- Navaja (Childrey 2009).

- Dakota/Lakota/Nakota (Lee et al. 2014).

- Inuítes (MacDonald 1998).

- Lapônica (Lundmark 1982).

- Egípcia (Belmonte 2003).

- Cultura Ocidental (documentos da União Astronômica Internacional ${ }^{9}$; OLIVEIRA; SARAIVA, 2014).

\footnotetext{
8 http://www.telescopiosnaescola.pro.br/indigenas.pdf

9 https://www.iau.org/public/themes/constellations/
} 


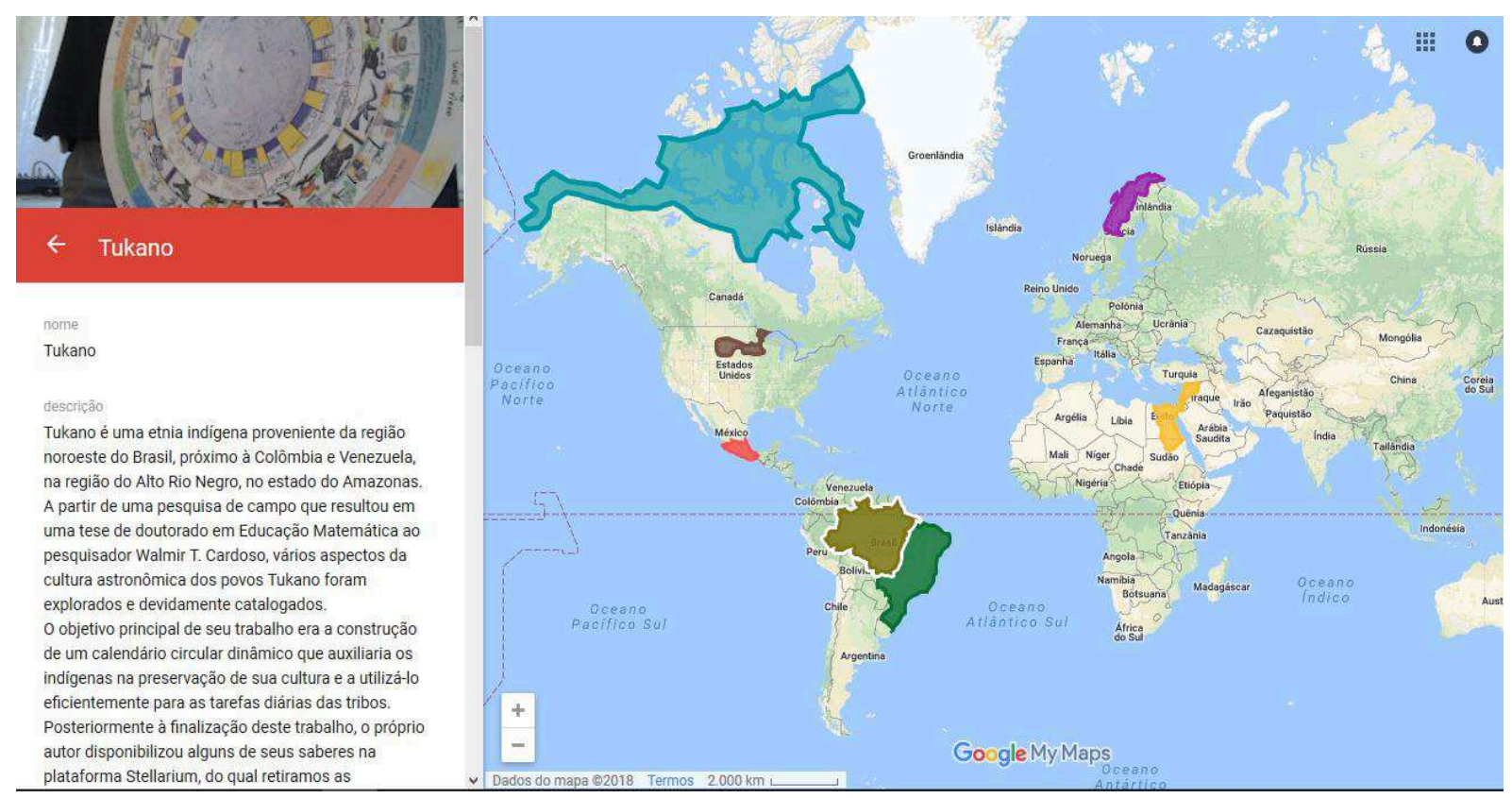

Fig. 10 - Localização, na Terra, das diferentes culturas estudadas no presente trabalho. 